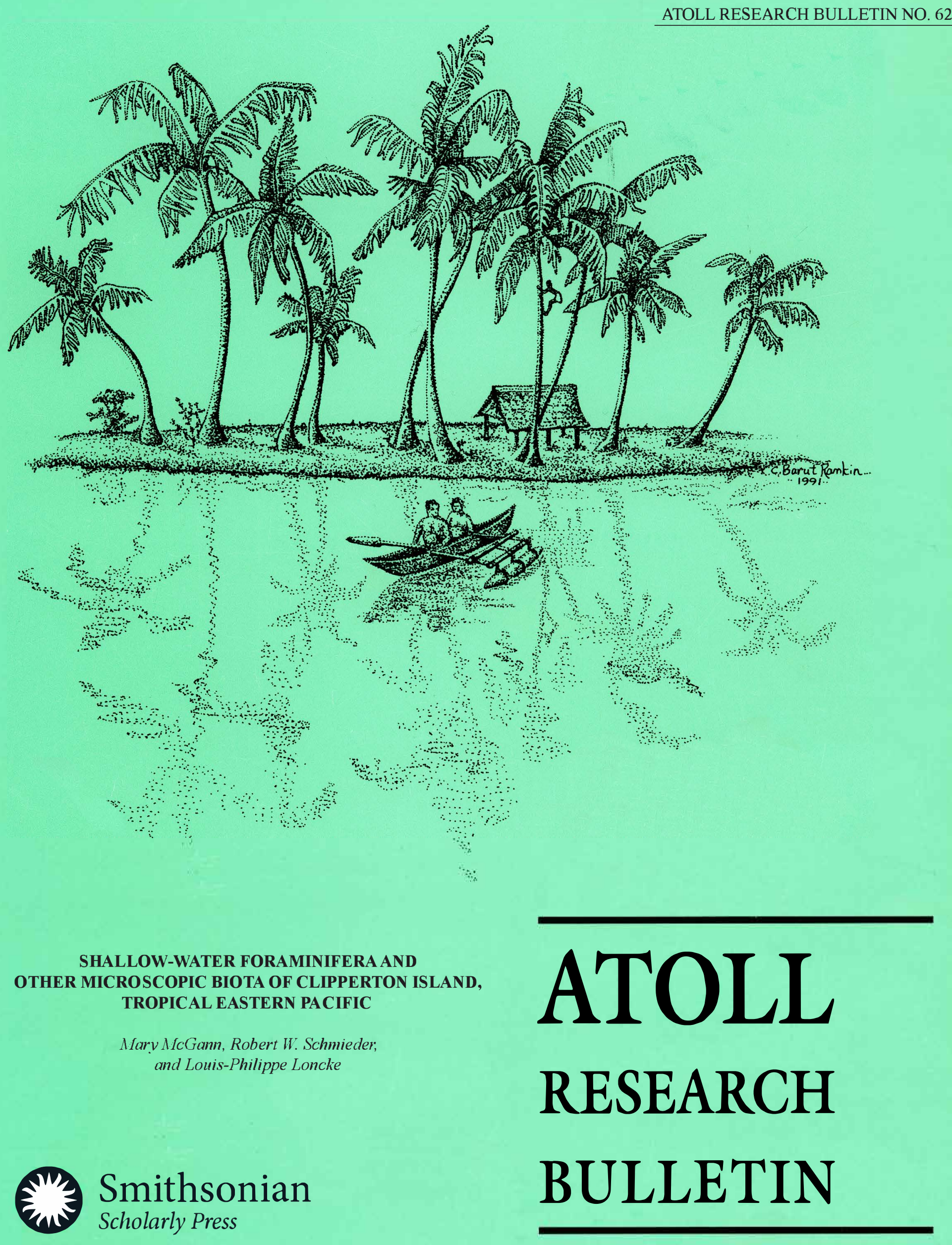





\title{
SHALLOW-WATER FORAMINIFERA AND OTHER MICROSCOPIC BIOTA OF CLIPPERTON ISLAND, TROPICAL EASTERN PACIFIC
}

\author{
Mary McGann, Robert W. Schmieder, \\ and Louis-Philippe Loncke
}

Atoll Research Bulletin No. 626 20 November 2019

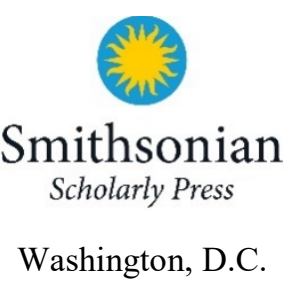


All statements made in papers published in the Atoll Research Bulletin are the sole responsibility of the authors and do not necessarily represent the views of the Smithsonian Institution or of the editors of the bulletin. Articles submitted for publication in the Atoll Research Bulletin should be original papers and must be made available by authors for open access publication under a CC-BY-NC license. Manuscripts should be consistent with the "Author Formatting Guidelines for Publication in the Atoll Research Bulletin." All submissions to the bulletin are peer reviewed and, after revision, are evaluated prior to acceptance and publication through the publisher's open access portal (https://smithsonian.figshare.com/ScholarlyPress).

Published by SMITHSONIAN INSTITUTION SCHOLARLY PRESS

P.O. Box 37012, MRC 957

Washington, D.C. 20013-7012

https://scholarlypress.si.edu/

ISSN: 0077-5630 (online)

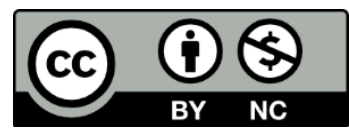

This work is licensed under a Creative Commons Attribution-NonCommercial 4.0 International License. 


\section{CONTENTS}

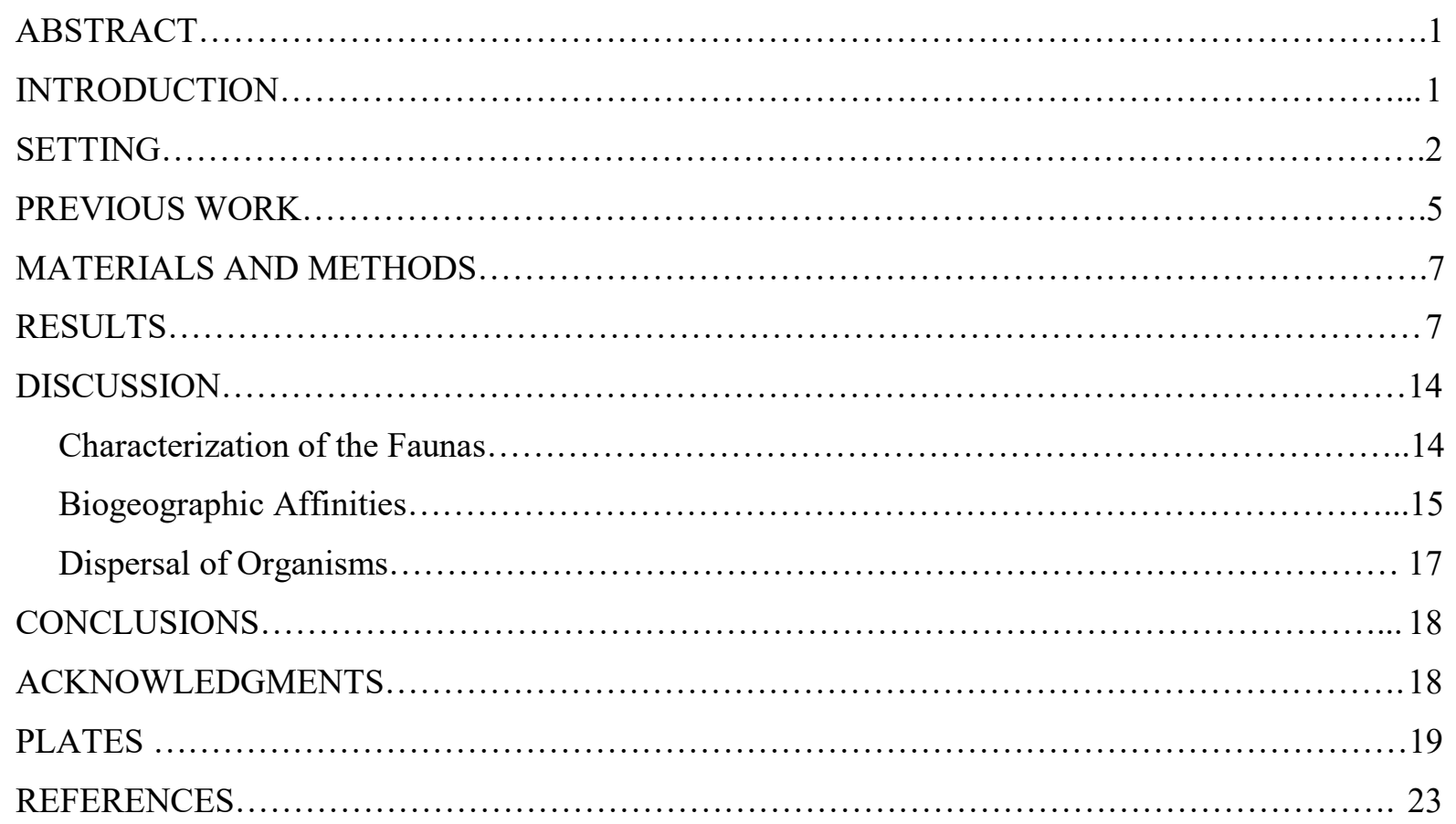





\title{
SHALLOW-WATER FORAMINIFERA AND OTHER MICROSCOPIC BIOTA OF CLIPPERTON ISLAND, TROPICAL EASTERN PACIFIC
}

\author{
MARY MCGANN ${ }^{1}$, ROBERT W. SCHMIEDER ${ }^{2}$, and LOUIS-PHILIPPE LONCKE ${ }^{3}$
}

\begin{abstract}
The recent foraminiferal fauna and associated microbiota of Clipperton Island $\left(10.2833^{\circ} \mathrm{N}\right.$, $109.2167^{\circ} \mathrm{W}$ ) were investigated at 20 sites collected in the intertidal zone around the perimeter of the island and from the edge of the inner brackish-water lagoon. Due to the island's geographic location in a low productivity zone, a lack of variable habitats on and surrounding the island, and heavy surf that pounds the exposed land, a depauperate fauna was recovered although mixed biogeographic affinities are represented. The shallow-water foraminiferal assemblage has no endemics but primarily tropical Indo-Pacific and eastern Pacific (Panamic) affinities, as well as one species of Caribbean affinity. The most abundant taxa are Sorites spp. and Quinqueloculina spp. Noticeably absent are any species of Amphistegina, despite the fact that they are considered ubiquitous in the tropical Pacific. The molluscan fauna has Clipperton Island endemics, a tropical Pacific/Inter-Island endemic, and tropical eastern Pacific oceanic islands/Panamic Molluscan affinities. The ostracods included endemics found restricted to Clipperton Island lagoon, as well as Indo-Pacific and Panamic Province species. The foraminifera, mollusks, and ostracods are thought to disperse to Clipperton Island by way of the North Equatorial Countercurrent and North Equatorial Current, suggesting that the island is indeed a stepping stone for migration both east and west across the Eastern Pacific Barrier.
\end{abstract}

\section{INTRODUCTION}

Clipperton Island is an uninhabited French island in the tropical eastern Pacific Ocean $\left(10.2833^{\circ}\right.$ $\left.\mathrm{N}, 109.2167^{\circ} \mathrm{W}\right)$, much nearer to the continental shores of Mexico $(1,100 \mathrm{~km})$, the Central American mainland $(1,300 \mathrm{~km})$, and the Revillagigedo Islands to the north $(\sim 1,000 \mathrm{~km})$ than to the nearest Pacific islands to the west (i.e., the Line Islands $5,700 \mathrm{~km}$ away) (Figure 1; Glynn et al., 1996). The island is of biogeographical significance because of its extreme isolation, situated between the vast $5000-\mathrm{km}$ Eastern Pacific Barrier (EPB) separating the tropical Indo-Pacific environment to the east (Ekman, 1953) and the tropical Eastern Pacific (Panamic Province) to the west (Figure 2; Ekman, 1953; Combasch et al., 2008).

The remoteness of the island stimulated scientific interest, culminating in the "2013 Cordell Expedition" to Clipperton Island in February-March. Two expedition members (RWS and L-PL) were responsible for capturing airborne insects with a kite-lofted net, observing congenitally deformed masked boobies, searching for an invasive big-headed ant, counting plastic debris, and collecting sediment around the island (Schmieder, 2013). These two participants, and the remainder of the expedition members, also conducted amateur ("ham") radio operations (TX5K; http:www.tx5k.org/), seeking to achieve radio com-munications over long distances and in exotic locales for brief periods of time. After the expedition, the sediment samples were returned to the United States where they were examined (by MM) for foraminifera and other microscopic animal and plant remains.

\footnotetext{
${ }^{1}$ U.S. Geological Survey, 345 Middlefield Road, Menlo Park, CA 94025, USA. Email: mmcgann@usgs.gov

${ }^{2}$ Cordell Expeditions, 4295 Walnut Blvd., Walnut Creek, CA 94596, USA. Email: schmieder@cordell.org

${ }^{3}$ Belgian Adventurer, 30 rue Alois den reep, 7700 Mouscron, Belgium. Email: BelgianAdventurer@gmail.com
} 


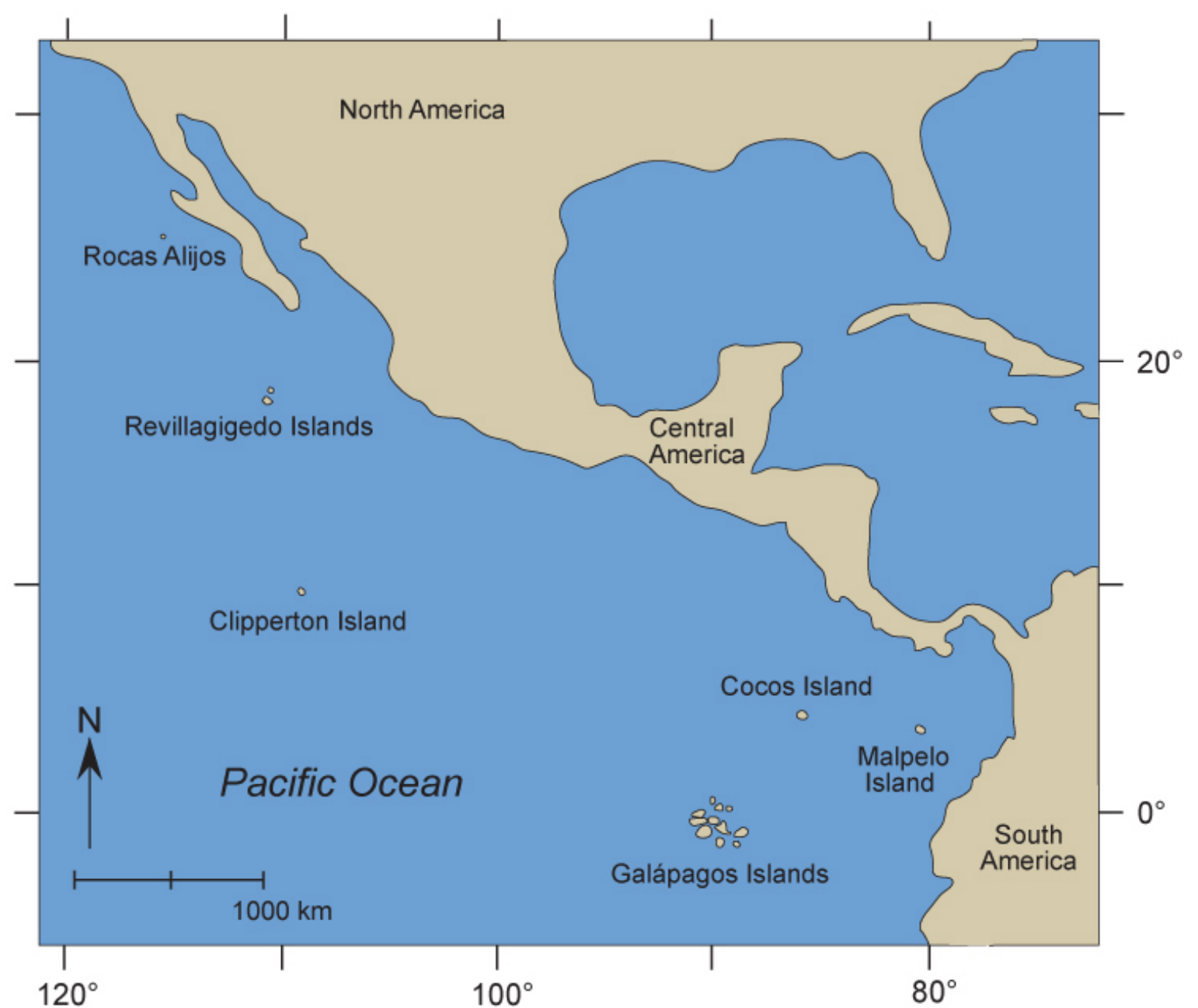

Figure 1. Location of Clipperton Island and other islands in the tropical eastern Pacific Ocean.

\section{SETTING}

Clipperton Island was first discovered by two Frenchmen, Martin de Chassiron and Michel Du Bocage, on April 3, 1711 who named it "Île de la Passion" ("Isla de la Pasión") as they sailed past it on the French schooners they commanded, the La Princesse and La Découverte, respectively (Skinner and Schmieder, 1996; Lévesque, 1998). The island is low and barren except for coconut palms that were originally planted in the early 1900s by Mexican troops stationed there (Figures 3A, 3B; Kaiser, 2007) and Clipperton Rock, a 22 m-high trachyte volcanic outcropping that lies on the southeastern edge of the island (Figures 3C, 4; Teall, 1898; Menard and Fisher, 1958). The island, therefore, is not a true atoll but an almost-atoll because of this small volcanic protrusion (Glynn et al., 1996; Goldberg, 2016). The surf continuously pounds the exposed land and due to the island's low relief, storms are thought to occasionally wash completely over it (Limbaugh, 1959; Kaiser, 2007).

Clipperton Island is an egg-shaped ring of consolidated coral rubble $\sim 2.7 \mathrm{~km}$ in diameter and $11.8 \mathrm{~km}$ in circumference, with only 1.7 square $\mathrm{km}$ of exposed land varying in width from 25-320 m (Figure 4; Kaiser, 2007). The ring surrounds a lagoon that makes up the majority (85\%) of the island. Originally, the 

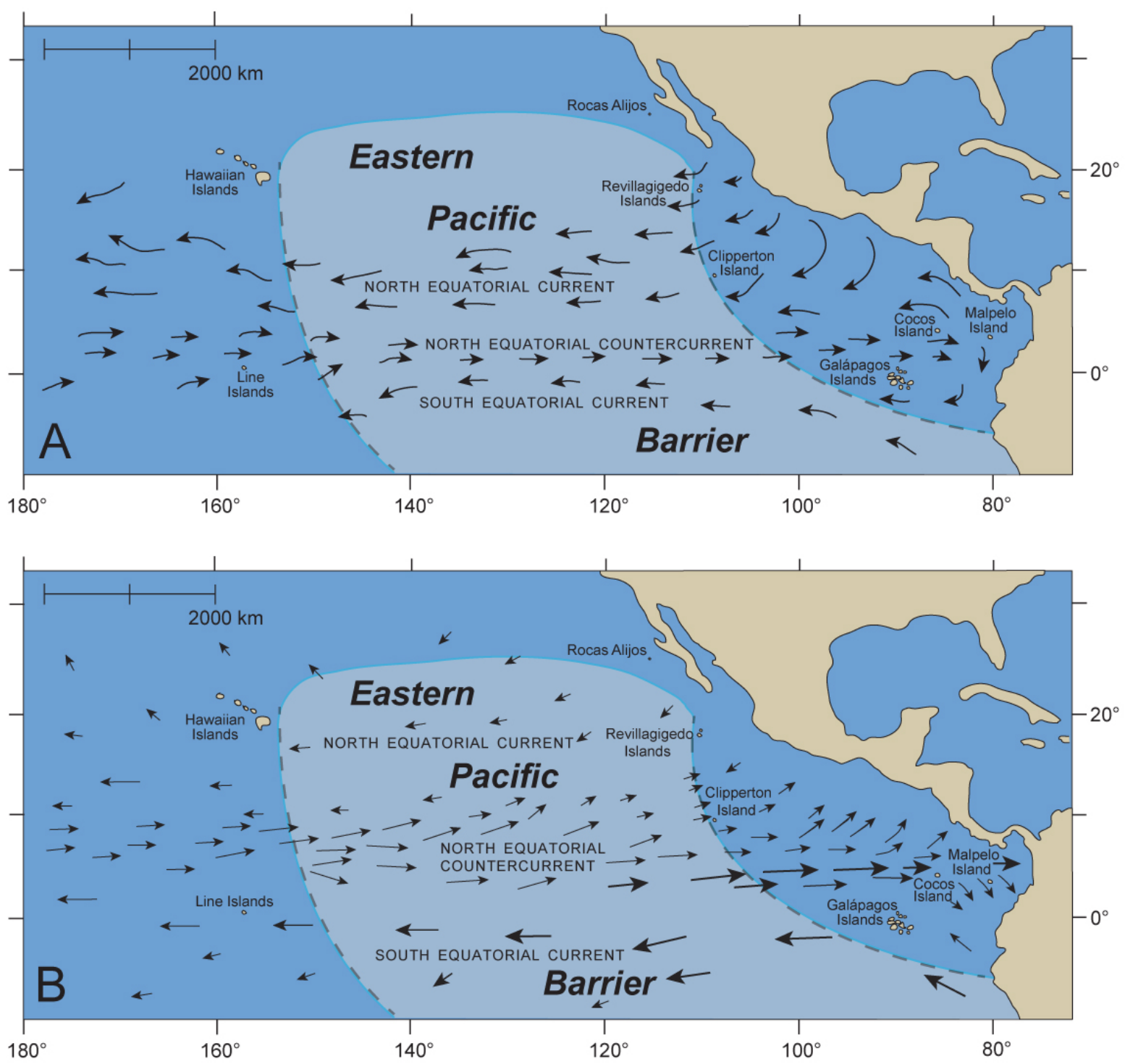

Figure 2. A. Generalized summary of the surface currents of the tropical central and eastern Pacific Ocean (modified from Geography Notes) and the approximate location of the Eastern Pacific Barrier (EPB) after Combosch et al. (2008). B. Currents shown for August when the North Equatorial Countercurrent is most pronounced (from Gorshkov, 1976). Current intensity on Figure 2B depicted by the thickness of the arrows, from $>0.5$ knots to $>1.5$ knots. After Glynn et al. (1996).

lagoon was open to the sea (Belcher, 1843; Sachet, 1963). This occurred by means of two passages, each on the NE and SE ends of the island, as shown on the first map drawn in 1939 (Charpy et al., 2010). Physical alterations due to hurricanes and severe storms most likely closed it off between 1839 and 1858 (Sachet 1962b), and certainly by 1861 (Skaggs, 1989). Charpy et al. (2010) suggest the lagoon was, in fact, closed by 1849 based on maps drawn in 1849 and 1858, and that the lagoon was completely transformed into a lake with fresh water at the surface by 1861 as reported by an American officer. The lagoon was still closed as of 2005 (Charpy et al., 2010) and 2007 (Kaiser, 2007), being brackish and plankton-rich at the surface, hydrogen sulfide-rich below 12-15 m, and gelatinous below $\sim 18-34 \mathrm{~m}$ (Kaiser, 2007), although occasional storm waves washing marine water into it may increase the salinity of the surface waters (Limbaugh, 1959). 

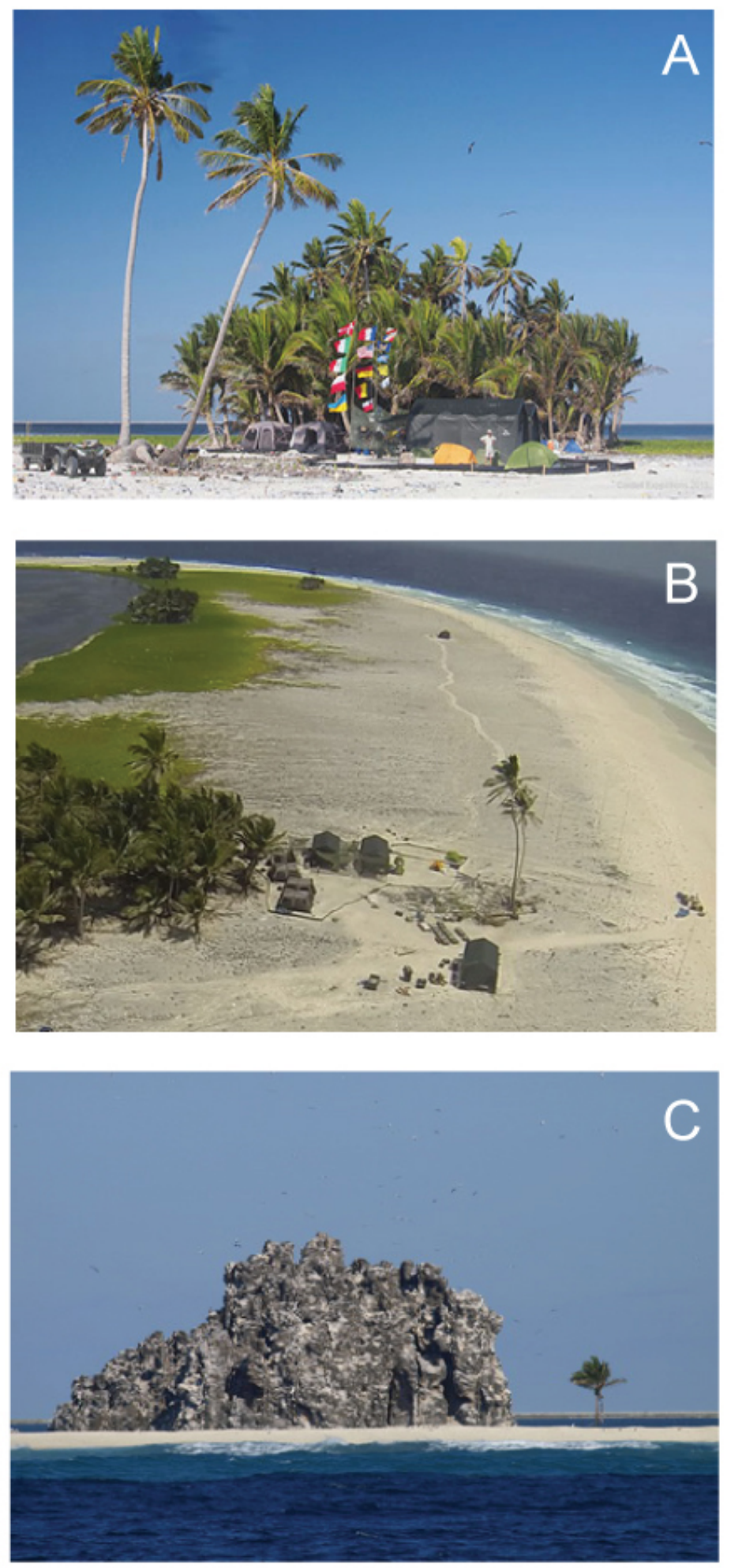

Figure 3. A. 2013 Cordell Expedition (TX5K) campsite on an open, flat sand deposit in front of a palm grove, with the lagoon in the background. B. Aerial photograph of the campsite. C. Clipperton Rock. Photographs courtesy of Cordell Expeditions (Schmieder, 2013). 
This closed, meromictic lagoon is unique among atoll lagoons worldwide (Charpy et al., 2010). It transformed over less than 150 years from a marine lagoon to a permanently stratified lagoon due to its separation from the ocean and a dilution effect from high seasonal rainfall, resulting in greater precipitation than evaporation (Charpy et al., 2010). However, marine salinities (27-33) measured in 2005 in a small shallow bay indicate the lagoon is no longer totally isolated from the marine realm (Charpy et al., 2010). Possibly some oceanic water entered through a sandy barrier near the site of the previous SE passage (Charpy et al., 2010) and may continue to do so in the future.

Oceanward of the inner lagoon and coral rubble ring lies an intertidal reef flat and a weakly developed algal ridge (Allison and Holden, 1971). Beyond this is a gentle slope incised by scoured-out channels that opens out onto a submerged terrace 100-200 $\mathrm{m}$ in width at a water depth of 10-20 m. Here, coral growth abounds and continues down to a depth of $\sim 30 \mathrm{~m}$.

Abyssal ocean depths lie between Clipperton Island, the mainland, and the other four islands in the far eastern tropical Pacific: the Revillagigedo Islands of Mexico, Cocos Island of Costa Rica, Malpelo Island of Colombia, and the Galápagos Islands of Ecuador (Figure 1). And whereas upwelling occurs along the coasts of Baja California, the Gulf of California, the Gulf of Panama, and Peru resulting in surface water temperatures fluctuating as much as $6-10^{\circ} \mathrm{C}$ between the cold upwelling winter months and the summer (Crouch and Poag, 1987), on Clipperton Island upwelling is absent due to the steep slopes and narrow shelf, such that water temperatures rise several degrees higher than that found near the mainland at the same latitude (Lindberg et al., 1980).

\section{PREVIOUS WORK}

The first scientific expedition on Clipperton Island is supposed to have occurred in 1725, during which time the expedition leader, the Frenchman M. Bocage, lived on the island for several months (Wikipedia, https://en.wikipedia.org/wiki/Clipperton_Island, accessed 24 May 2019). However, Sachet (1960) reports the first landing on the island is supposed to have been made by a U.S. sailor (Benjamin Morrell) in 1825. A little more than a century later, from 1932 to 1938, the Allan Hancock Pacific Expeditions utilized the $\mathrm{R} / \mathrm{V}$ Velero III to collect both macro- and microorganisms in the eastern Pacific Ocean in bottom dredges off the coasts of the United States, Mexico, Central America, South America, and the Galapagos Islands. The collections were incorporated into the Allan Hancock Foundation at the University of Southern California in Los Angeles, California. Faunal slides of the foraminifera collected during the expedition are now housed at the Santa Barbara Museum of Natural History in Santa Barbara, California. Of the $>900$ stations samples, one sample (427) was obtained off Clipperton Island at a shallow, but undescribed, depth at $10.2833^{\circ} \mathrm{N}, 109.2167^{\circ} \mathrm{W}$ on January 6,1934 (Cushman and McCulloch, 1939). Two benthic foraminifera from this locality were identified in McCulloch's original field notebook which is part of the museum's library and in the later foraminiferal faunal compilations (Cushman and McCulloch, 1948 and 1942, respectively): Angulogerina albatrossi Cushman var. ornata Cushman and Loxostomum limbatum (H. B. Brady). McCulloch (1977) later described the findings of the expeditions in greater detail, identifying 21 additional species at the Clipperton Island site (Table 1), including eight that were type specimens.

As part of the 1957-1958 International Geophysical Year (IGY) expedition "DOLDRUMS," the University of California Scripps Institution of Oceanography was tasked with describing the geography, geology, and biology of Clipperton Island using the R/V Spencer F. Baird (IGY Clipperton Island Expedition; Sachet, 1960, 1962a, 1962b, 1962c, 1963). Their first visit actually occurred in OctoberNovember 1956 and a second in August-September 1958, during which time they collected enough flora and fauna to significantly increase the number of known organisms. The expedition summary (Limbaugh, 1959) also mentions collecting foraminifera and states that they would be housed at the University of 
Table 1. Species identified by McCulloch (1977) at Clipperton Island. ${ }^{1}$ Taxa and taxon inquirendum with Clipperton Island as the type locality

Briceia sp. A McCulloch, $1977=$ Briceia (?) sp. A in McCulloch (1977)

${ }^{1}$ Coryphostoma clippertonense McCulloch, 1977 = Coryphostoma clippertonensis in McCulloch (1977)

Cycloforina semiplicata (McCulloch, 1977) = Quinqueloculina semiplicata in McCulloch (1977)

${ }^{1}$ Ehrenbergina clippertonensis McCulloch, 1977

Fissurina evolutiformis McCulloch, 1977

Fissurina sulphurensis McCulloch, 1977

${ }^{1}$ Glandulina clippertonensis McCulloch, 1977 = Glandulina? clippertonensis in McCulloch (1977)

${ }^{1}$ Globigerina clippertonensis McCulloch, 1977 (taxon inquirendum)

Globigerina galapagosensis McCulloch, 1977 (taxon inquirendum)

Globigerina hybrida McCulloch, 1977 (taxon inquirendum)

Globigerinella siphonifera (d'Orbigny, 1839) = "Globigerinella" aequilateralis (Brady, 1879) in

McCulloch (1977)

Gypsina cf. G. vesicularis (Parker \& Jones, 1860)

${ }^{1}$ Lagena clippertonensis McCulloch, 1977

Neohauerina socorroensis McCulloch, 1977

Quinqueloculina angustiformis McCulloch, 1977

${ }^{1}$ Quinqueloculina subparkeri McCulloch, 1977

Quinqueloculina (?) sp. G

${ }^{I}$ Rectobolivina clippertonensis McCulloch, 1977

Spirillina seymourensis McCulloch, 1977

${ }^{1}$ Svratkina clippertonensis McCulloch, 1977 = Svratkina (?) clippertonensis in McCulloch (1977)

Turrispirillina simplissima McCulloch, 1977

California Museum of Paleontology in Berkeley. Unfortunately, those collections cannot be found (Finger, personal communication, 2013).

IGY Clipperton Island Expedition sediment and algae samples collected by free and SCUBA diving, as well as a single dredge (station B-8558), provided samples for an investigation of ostracodes from the island (Allison and Holden, 1971). Brackish lagoon, marine reef, and off-reef habitats were sampled, with species abundances, living versus nonliving specimens, and distributional relationships discussed.

In 1987, Crouch and Poag published a study of eastern Pacific inner continental shelf benthic foraminifera of the Panamanian Province, encompassing $49^{\circ}$ latitude from Baja California Norte $\left(32.5^{\circ} \mathrm{N}\right)$ to southern Peru $\left(16.5^{\circ} \mathrm{S}\right)$ and $\sim 9,300 \mathrm{~km}$ of coastline. The samples were collected as grabs at the sediment surface by SCUBA divers and were provided primarily by the Natural History Museum of Los Angeles County (NHM). Unfortunately, the dates of sampling were not published, and the original slides and sample residues could not be located by NHM staff. Only dead specimens were reported, including 229 species from 96 stations at 33 localities. Two of the stations (21 and 22) were off Clipperton Island, from which 33 species of benthic foraminifera were identified.

The investigations of Clipperton Island mollusks far outnumber those of the foraminifera. Franklin D. Roosevelt's Presidential Cruise of 1938 on board the USS Houston collected 12 species of mollusks, five of which were new species (Bartsch and Rehder, 1939). Between 1975 and 1980, several small expeditions were sent to Clipperton Island to acquire information relevant to a development plan for the island of interest to the French government (Kaiser, 2007). The focus of the 1980 trek undertaken by French, Canadian, and U.S. scientists and divers, led by Jacques Cousteau (1981) and his vessel Calypso, was an investigation of the inner lagoon as well as the birds and land crabs, yet a few worn mollusk shells were also collected on the beach. Two stations were investigated by Cousteau and S. Luke. In addition to 
polychaete worms, decapods, isopods, sponges, and echinoderms among other invertebrates, eight species of gastropod, one cephalopod, and two bivalves were collected by hand at Station $1\left(10.2833^{\circ} \mathrm{N}\right.$, 109.2167 ${ }^{\circ}$ W, S.W. reef in front of Palm Grove and French barracks) on March 13, 1980, and 11 species of gastropod and one bivalve were collected at Station $2\left(10.3^{\circ} \mathrm{N}, 109.2167^{\circ} \mathrm{W}\right.$, N. end at opening to ocean $)$ two days later (Figure 4; Benthic Invertebrate Collection at Scripps, 2019).

Sport and commercial fisherman frequent the waters surrounding Clipperton Island as well, in search of large tuna and other fish. Some of them took the time to land on the island, later documenting the difficult landing conditions they encountered and the mollusks they collected along the beach (Perrin, 1977; Schneider, 2004).

In 1994, Emerson published a comprehensive zoogeographic summary of the 92 species of mollusks from Clipperton Island known up to that time that preceded the Santa Barbara Museum of Natural History's "Clipperton 1994 Expedition". The purpose of the latter was to explore the mollusks of the undersea environment around the island using SCUBA, dredging, and tangle net deployments off the M/V Royal Star (Kaiser, 2007). Preliminary findings of the expedition were published by Small $(1994,1995)$ and Beals (1995). Although several other major expeditions were undertaken at Clipperton Island shortly thereafter (i.e., the 1997 Universidad Nacional Autónoma de México "SURPACLIP-I" and the French "Passion 2001"; Jost and Andrefouët, 2006), those most relevant to the present study are the 1998 Smithsonian Tropical Research Institute "STRI Clipperton Expedition," the 2004-2005 French "Expédition Clipperton," and the "Expedition Île Clipperton 2007." The results of these molluscan investigations are summarized by Kaiser (2007), in which the total number of known species increased by $210 \%$, to 285 .

\section{MATERIALS AND METHODS}

Sediment samples were taken by hand at 17 locations in the intertidal zone around the perimeter of the island as well as three locations from the margin of the inner brackish-water lagoon (Figures 4, 5; Table 2). In order to identify those individuals that were alive, or recently alive, at the time of collection (Bernhard, $1988,2000)$, the samples were immersed in a mixture of $2 \mathrm{~g}$ of rose Bengal stain per 1 liter of $>70 \%$ ethyl alcohol (Lutze and Altenbach, 1991) and left to soak for a month until the samples were returned from the field. The samples were then wet-sieved through nested $1.0 \mathrm{~mm}, 0.150 \mathrm{~mm}$, and $0.063 \mathrm{~mm}$ screens to remove the clay fraction and excess stain, transferred to filter paper, and allowed to air dry. Because specimens were scarce, no microsplitter was used. Instead, the $>0.063 \mathrm{~mm}$ size fraction of each sample was picked for foraminifera and other microbiota, placed on microslides, and identified. The microslides are on file at the U.S. Geological Survey in Menlo Park, California.

A Tescan Vega3 tungsten thermionic emission scanning electron microscope (SEM) housed at the U.S. Geological Survey in Menlo Park provided the micrographs of the foraminifera and other microscopic biota (Plates 1-3). The accelerating voltage for the electrons (HV) was $10.0 \mathrm{kV}$.

\section{RESULTS}

Twenty-nine taxa of benthic foraminifera and two species of planktic foraminifera were recovered from the 20 Clipperton Island samples (Tables 3, 4; Plate 1). In addition to the foraminifera, remains of other biologic groups were collected (Tables 3, 5; Plates 2, 3). Among the surf and beach samples, these include 15 species of gastropod, gastropod opercula, four species of ostracod, bivalve mollusks, bryozoans, crab claws, sea urchin spines, and worm tubes. In the inner lagoon, the remains of fish (bones and teeth), bivalve mollusks, gastropods, four species of ostracod, five benthic foraminiferal species, a winged insect, a tiny mammal bone (i.e., likely a proximal metapodial such as a second metatarsal; Plate 2, R) of a mouse-size animal (Samuels, written communication, 2018), seeds of aquatic plants (e.g., Scirpus), and charophyte 
gyrogonites (i.e., calcium carbonate algal reproductive structures) were encountered. No living specimens were found among any of the biota collected.

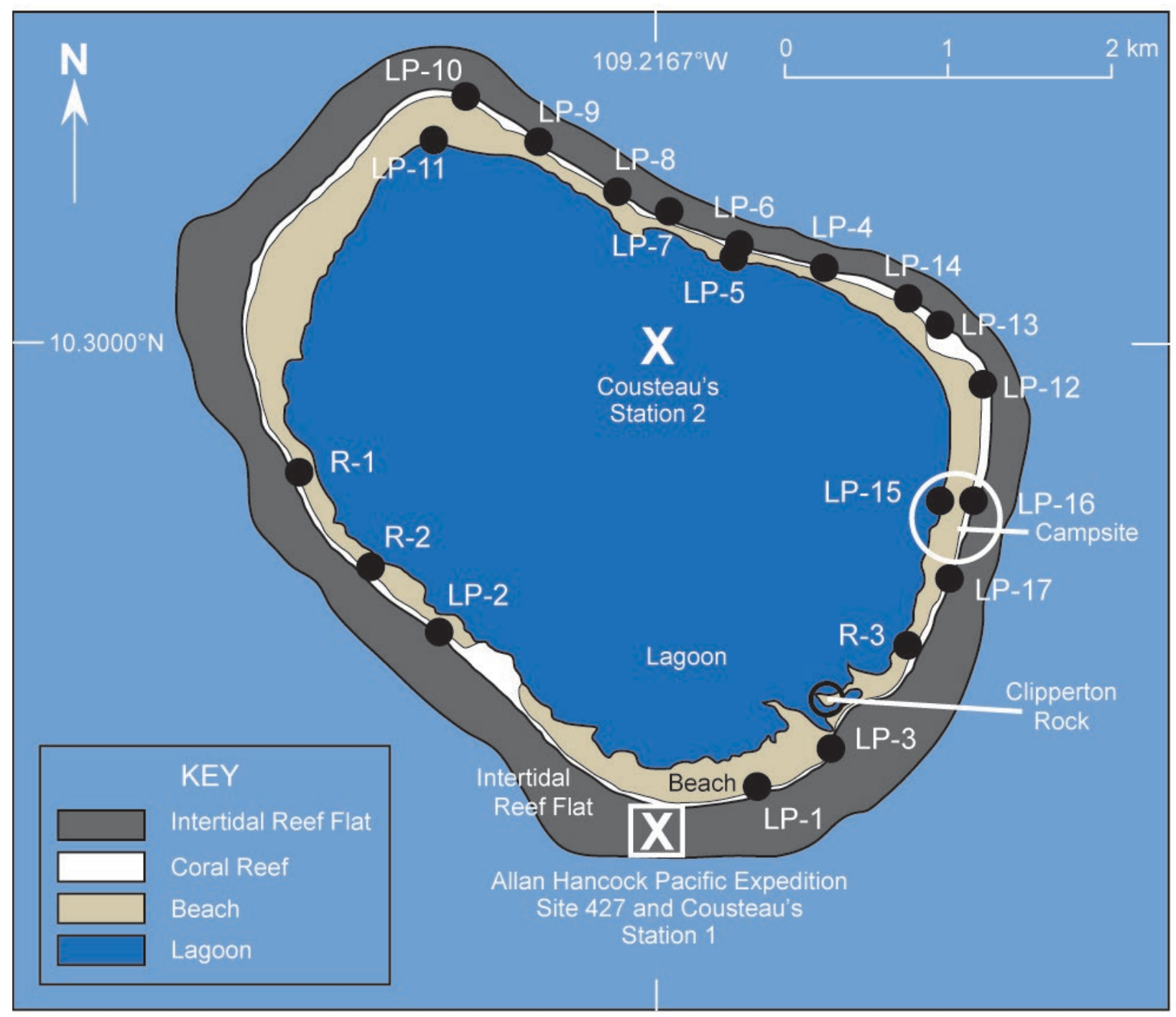

Figure 4. Map of Clipperton Island, showing the location of the 2013 Cordell Expedition (TX5K) campsite (white circle), the location of Clipperton Rock (black circle), the 20 sampling sites (black dots), the location of Cousteau's two sampling sites in March 1980 (X; Benthic Invertebrate Collection at Scripps, 2019), and the location of the Allan Hancock Pacific Expedition Station 427 in January 1934 (white square; Cushman and McCulloch, 1939). LP, samples collected by Louis-Philippe Loncke; R, samples collected by Robert W. Schmieder. Cousteau's Station 2 was reported to be at the north end of the island at the opening to the ocean but plots at the northern end of the lagoon and, therefore, may not be properly located. 

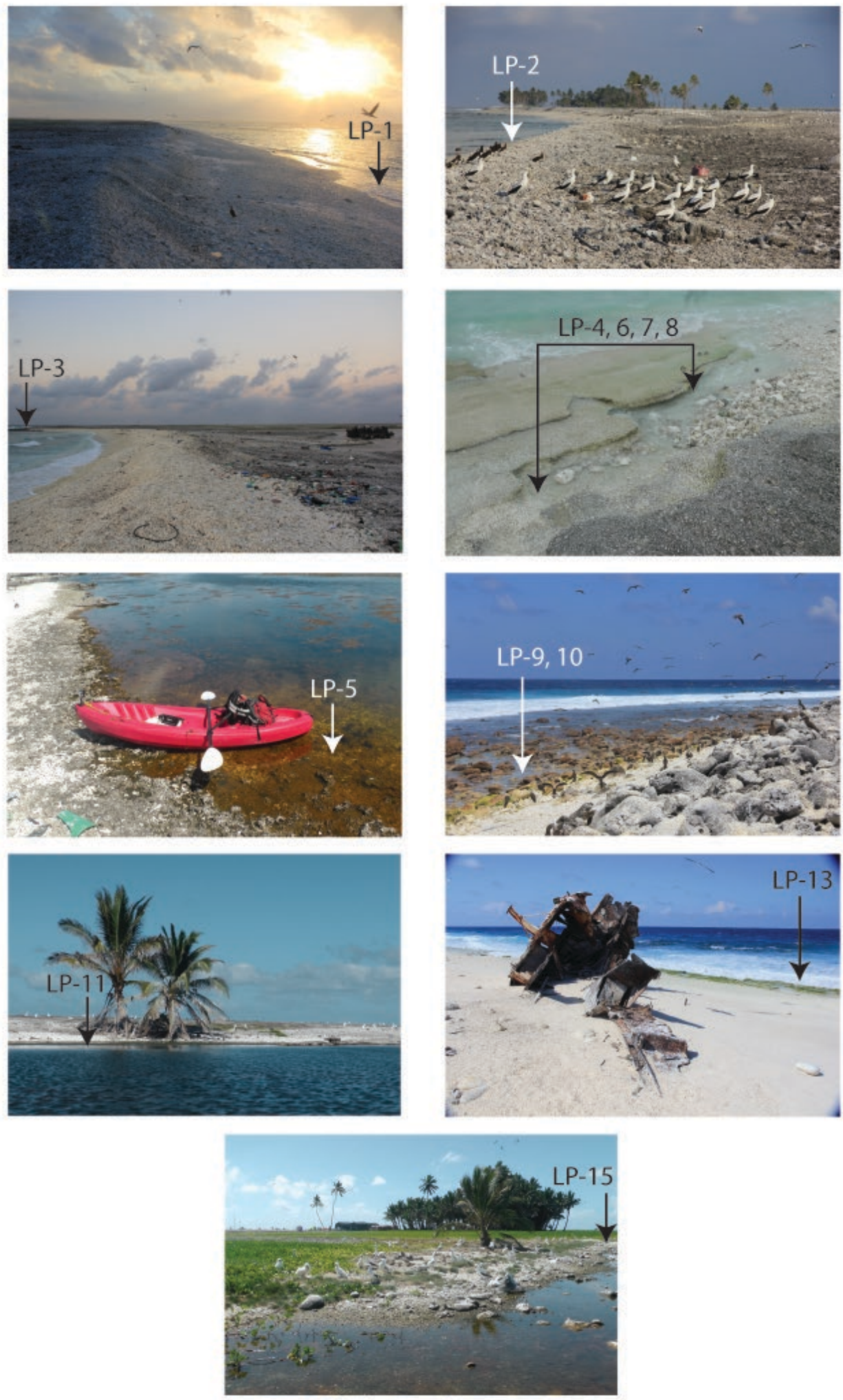

Figure 5. Clipperton Island sampling sites. Photographic documentation of sites LP-12, LP-14, LP-16, LP17, and R1-3 are not available. 
Table 2. Sample number, collection date, location (latitude and longitude), water depth (cm), and generalized location of the Clipperton Island samples

\begin{tabular}{cccccc}
$\begin{array}{c}\text { Sample } \\
\text { Number }\end{array}$ & Collection Date & Latitude $\left({ }^{\circ} \mathrm{N}\right)$ & Longitude $\left({ }^{\circ} \mathrm{W}\right)$ & $\begin{array}{c}\text { Water } \\
\text { Depth }(\mathrm{cm})\end{array}$ & Location \\
\hline LP-1 & March 8, 2013 & 10.287897 & 109.210928 & $20-30$ & beach \\
LP-2 & March 8, 2013 & 10.295300 & 109.225369 & $20-30$ & beach \\
LP-3 & March 8, 2013 & 10.289708 & 109.207044 & $20-30$ & beach \\
LP-4 & March 9, 2013 & 10.311964 & 109.208103 & $20-30$ & beach \\
LP-5 & March 9, 2013 & 10.312319 & 109.211461 & $20-30$ & lagoon \\
LP-6 & March 9, 2013 & 10.312761 & 109.211383 & $20-30$ & beach \\
LP-7 & March 9, 2013 & 10.314256 & 109.215233 & $20-30$ & beach \\
LP-8 & March 9, 2013 & 10.315208 & 109.217258 & $20-30$ & beach \\
LP-9 & March 9, 2013 & 10.317469 & 109.220811 & $20-30$ & beach \\
LP-10 & March 9, 2013 & 10.319128 & 109.22365 & $20-30$ & beach \\
LP-11 & March 9, 2013 & 10.317433 & 109.224017 & $20-30$ & lagoon \\
LP-12 & March 9, 2013 & 10.306222 & 109.200275 & $20-30$ & beach \\
LP-13 & March 9, 2013 & 10.308867 & 109.201981 & $20-30$ & beach \\
LP-14 & March 9, 2013 & 10.310442 & 109.204081 & $20-30$ & beach \\
LP-15 & March 9, 2013 & 10.301031 & 109.202308 & $20-30$ & lagoon \\
LP-16 & March 9, 2013 & 10.301025 & 109.200572 & $20-30$ & beach \\
LP-17 & March 9, 2013 & 10.297461 & 109.201783 & $20-30$ & beach \\
R-1 & March 7, 2013 & 10.302778 & 109.231944 & $20-30$ & beach \\
R-2 & March 7, 2013 & 10.297778 & 109.228278 & $20-30$ & beach \\
R-3 & March 7, 2013 & 10.294667 & 109.203389 & $20-30$ & beach \\
& & & & & \\
\hline
\end{tabular}


Table 3. Microbiological constituents recovered on Clipperton Island

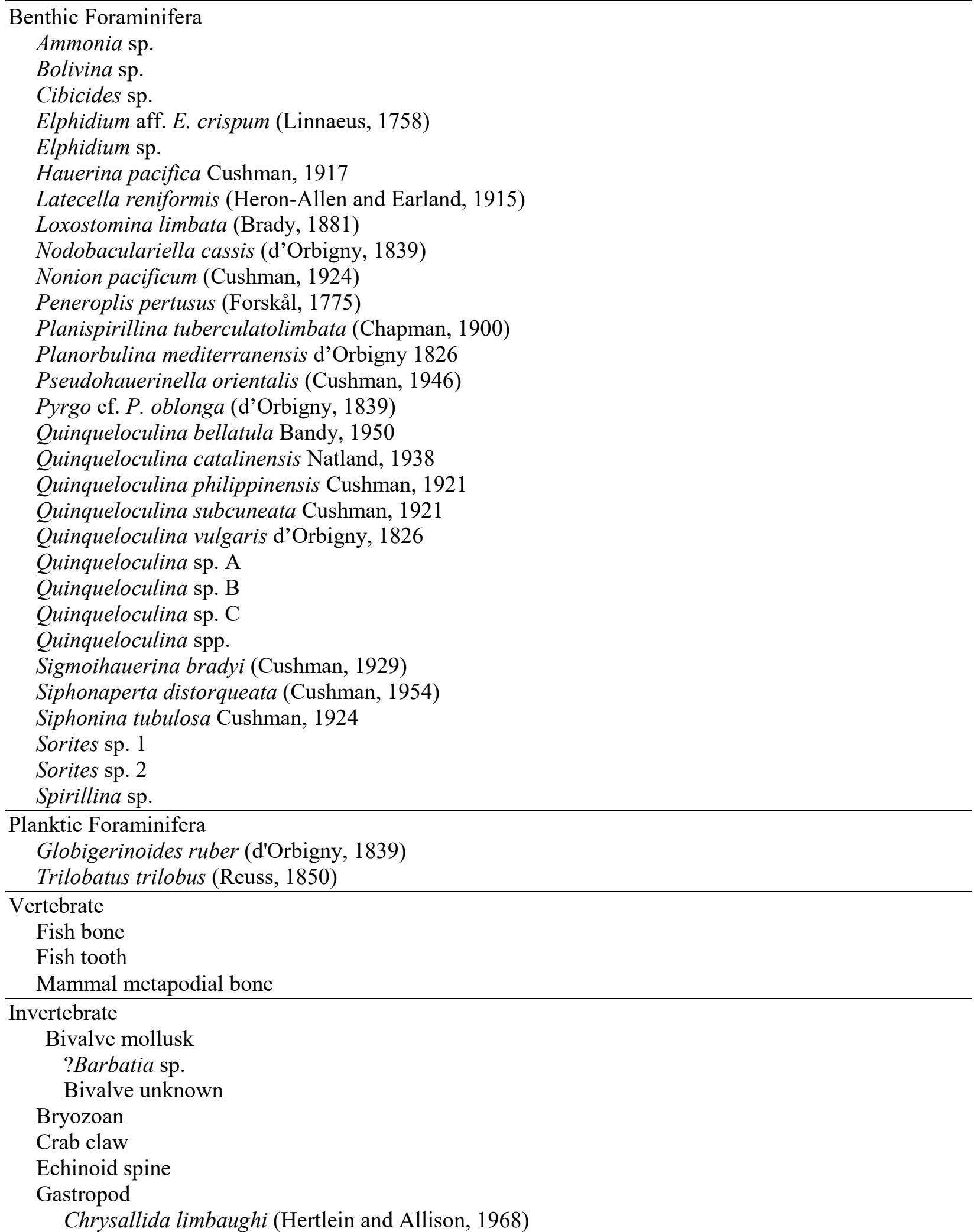

(continued on next page) 
Table 3. (continued)

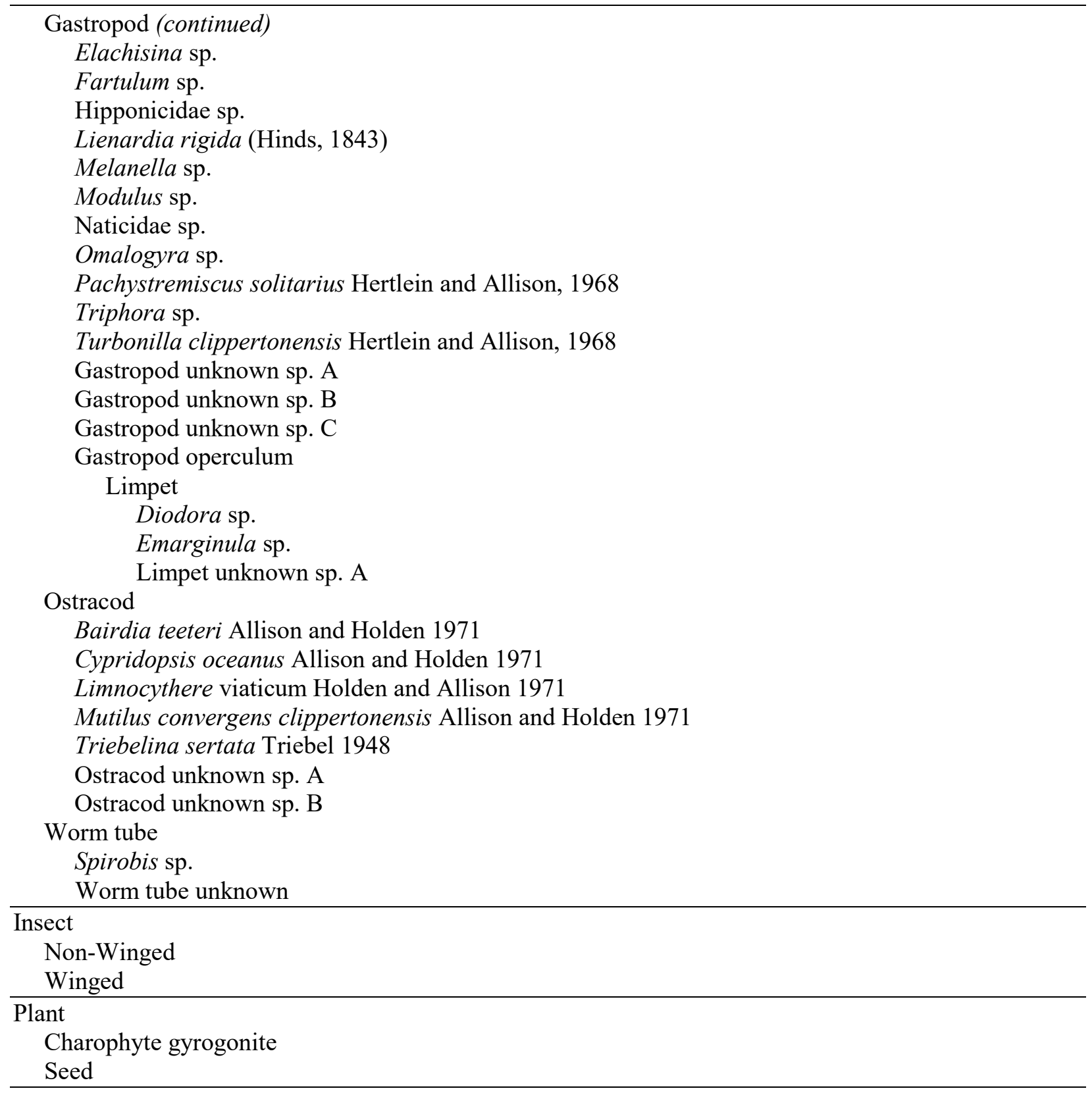


Table 4. Distribution (presence/absence) of foraminifera in the Clipperton Island samples

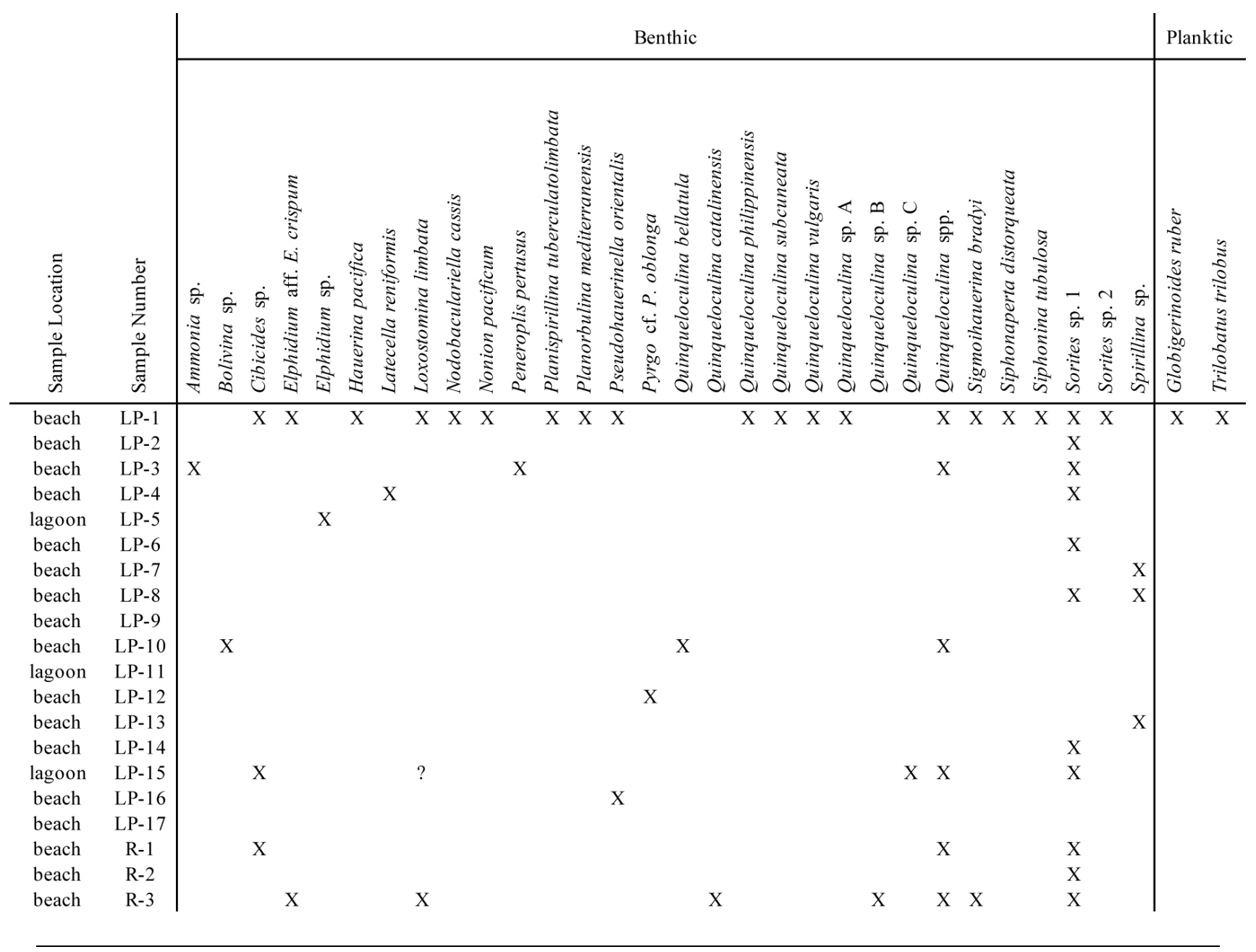


Table 5. Distribution (presence/absence) of microscopic vertebrate, invertebrate, insect, and plant remains in the Clipperton Island samples

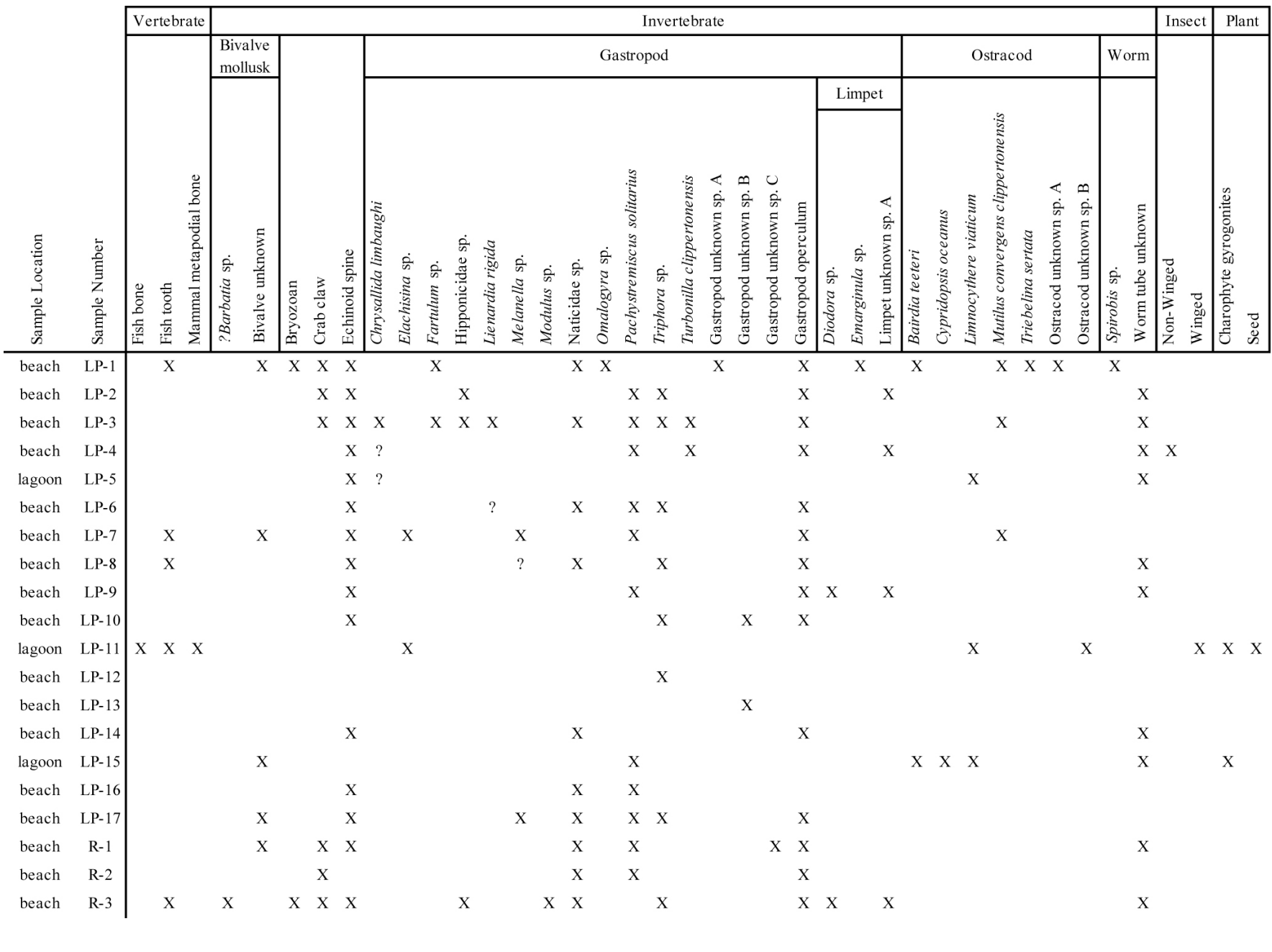

\section{DISCUSSION}

The extreme isolation of Clipperton Island prompts several inquiries. What are the characteristics of the faunas? Are the faunas of mixed biogeographic affinities (i.e., the tropical eastern Pacific [Panamic] and Indo-Pacific Provinces) or just local or Inter-Island endemics? And if other provinces are represented, how do these organisms disperse to this location?

\section{Characterization of the Faunas}

Though most tropical islands have numerous habitats where organisms can live (i.e., muddy, silty, and sandy bottoms, rocky shorelines), and extensive plant life near the water such as mangrove forests and algal mats that serve as both refuge and food sources, these are lacking on Clipperton Island. Instead, coral and coral rubble covers extensive areas. Additionally, the island's geographic location places it in one of the lowest productivity zones of the eastern Pacific (Koblentz-Mishke, 1970; Parsons and Takahashi, 1973), 
and the pounding surf around the entire island pulverizes biotic and sedimentologic debris that is eventually deposited in the surf zone and along the beach.

As a result of these limiting environmental factors, foraminiferal diversity is extremely low in the shallow-water environments around Clipperton Island compared to other islands in the tropical Pacific. Whereas almost 100 species were recovered in a very shallow-water coastal mangrove forest on Moorea (Langer and Lipps, 2006) and hundreds to thousands of species are typically encountered elsewhere on islands in the tropical Pacific (e.g., Makled and Langer, 2011; Debenay, 2012; Fajemila et al, 2015), only 29 taxa were recovered in this study (Table 4). The most common taxa are Sorites spp. and Quinqueloculina spp. The Sorites are further separated into two species: the most prevalent is Sorites sp. 1, characterized by a double row of apertures on edge view (Plate 1E, 1F), and Sorites sp. 2, with a single row of apertures on edge view (Plate 1G). Molecular data on the genus are inconclusive at this time (Holzmann et al., 2001; Merkado et al., 2013), with both apertural arrangements recently being attributed to the genus Sorites (Merkado et al., 2013).

Noteworthy is the apparent absence of any specimens of Amphistegina. The genus is reported to be ubiquitous in the tropical Pacific (Langer and Hottinger, 2000; Langer and Lipps, 2003), most often as Amphistegina lobifera Larsen or Amphistegina lessonii d'Orbigny, and often comprises a significant portion of the local sediment (Cushman et al., 1954; McKee et al., 1959; Moberly and Chamberlain, 1964; Sournia, 1976; Hallock, 1981; Vénec-Peyré, 1991; Whittaker and Hodgkinson, 1995; Bicchi et al., 2002; Debenay, 2012; Weinmann et al., 2013; Fajemila et al, 2015; Fujita and Omori, 2015). However, species of Amphistegina have not been encountered in the far eastern tropical Pacific, based on early surveys from California to Central America summarized by Culver and Buzas $(1986,1987)$, as well as in more localized investigations such as in the transitional boundary zone between the Surian and Panamanian Provinces off Baja California, Mexico (at Rocas Alijos; McGann, 1996), the southern Gulf of California (Halfar et al., 2000; Halfar and Ingle, 2003), the Panamanian Province from southern Baja California to southern Peru (Crouch and Poag, 1987), the Galápagos Archipelago (Humphreys et al., 2019), or in the Chilean-Peruvian Province (Boltovskoy, 1976). As Crouch and Poag (1987) as well as Langer and Hottinger (2000) suggested, species' distributions are controlled by water mass temperatures so it is possible that this genus is not represented in the far eastern tropical Pacific because it is not able to survive the cooler surface water temperatures in some areas, the seasonal effects of upwelling, or periodic episodes of cool eastern boundary currents penetrating into areas of warmer water.

Similar to the foraminifera, the diversity of the molluscan and ostracod faunas are impoverished at Clipperton Island compared to others in the tropical Pacific (Kaiser, 2007; Allison and Holden, 1971). Of the already meager molluscan fauna of just 285 species reported by Kaiser (2007), only 13 gastropods and 3 limpets were identified in this study. Nine of the 24 ostracod species reported by Allison and Holden (1971) were also recovered.

Because of the lagoon's isolation from the marine realm, the biota recovered there is somewhat distinct from the beach samples. The brackish water supports two species of ostracod (Cypridopsis oceanus and Limnocythere viaticum), aquatic plants (seeds of Scirpus), algae (charophyte gyrogonites), and fish (bones and teeth). However, the remains of marine-dwelling foraminifera (Sorites spp., Cibicides sp., Elphidium sp., and Quinqueloculina sp.), mollusks (Pachystremiscus solitarius and Elachisina sp.), and worm tubes, as well as the terrestrial-dwelling mammal (metapodial bone) are thought to be allochthonous, most likely transported to the lagoon from the marine realm and beach by waves sweeping over the island or, in the case of the mammal bone, from the limited land surface.

\section{Biogeographic Affinities}

The Clipperton Island biota, as determined by some of the earliest investigations, represent several faunal provinces. Bartsch and Rehder (1939), while reporting on the mollusks obtained on Roosevelt's 1938 Presidential Cruise, commented that the fauna was interesting and had an Indo-Pacific relationship that suggested it was a "drift fauna" (i.e., not endemic but carried by currents to this location). Additional 
molluscan specimens collected a few decades later also suggested the shallow marine fauna of Clipperton Island was dominantly a mixture of Indo-Pacific and Panamic species, although lesser elements included Californian-Panamic, endemic, and cosmopolitan-circumtropical taxa (Hertlein and Emerson, 1953; Emerson, 1967, 1994; Emerson and Chaney, 1995). This was followed by an investigation by Kaiser (2007) who noted several biogeographical affinities in the molluscan fauna: tropical eastern Pacific (Panamic, $37.7 \%$ ), Indo-Pacific (33.5\%), inter-island endemics (8.9\%), circumtropical (16.2\%), endemic (2.6\%), and western Atlantic (1.0\%). Despite the low diversity of the molluscan species recovered in the present study, several biogeographic regions are represented: Chrysallida limbaughi and Turbonilla clippertonensis are endemic to Clipperton Island, Pachystremiscus solitarius is a tropical Pacific, Inter-Island endemic species, and Lienardia rigida is a tropical eastern Pacific species associated with the Panamic and/or Californian Province and tropical eastern Pacific oceanic islands (Revillagigedo Islands, Cocos Island, Malpelo Island, and Galápagos Islands; see Kaiser, 2007).

Allison and Holden (1971) reported on the ostracods collected during the 1958 IGY Clipperton Island Expedition, commenting that the fauna was derived from four biogeographical regions: a distinct Caribbean aspect, a weak Indo-Pacific link, a restricted west American aspect, and a cosmopolitan aspect. They also noted that some distinct species (i.e., the Family Loxoconchidae) from comparable Indo-Pacific habitats were missing on the island. In the depauperate ostracod fauna recovered in this study, Cypridopsis oceanus and Limnocythere viaticum are two of the nine endemic freshwater species Allison and Holden (1971) found restricted to the lagoon due to its isolation from the ocean for the last $\sim 160$ years, Mutilus convergens clippertonensis is a shallow marine species also reported from the Panamic Province in the Gulf of California and Gulf of Panama, and Triebelina sertata is another shallow marine species but with IndoPacific as well as Caribbean affinities (Allison and Holden, 1971).

Other marine organisms from Clipperton Island also display mixed biogeographic affinities to the tropical eastern Pacific (Panamic Province) and Indo-Pacific. These include fish (Briggs, 1961; Allen, 1995, Robertson and Allen, 1996), corals (Glynn et al., 1966; Carricart-Ganivet \& Reyes-Bonilla, 1999; Flot and Adjeroud, 2009; Romero-Torres et al., 2018), crustaceans (Poupin et al., 2009), and echinoderms (SolisMarin and Laguarda Figueras, 2009). Although remains of many of these organisms were recovered in this present study, none were identified with a degree of taxonomic precision suitable to distinguish their biogeographic affinities.

Like the mollusks and ostracods, the Clipperton Island benthic foraminiferal fauna has affinities to more than one biogeographic province as well, as do the faunas of other tropical regions (see Förderer and Langer, 2018; Förderer et al., 2018). Crouch and Poag (1987) published the most complete inventory of benthic foraminifera from the island, although it is only based on two samples. They concluded that 58 of their eastern Pacific species had western Pacific affinities and 29 of 57 species from the Panamanian Province also had affinities to the western Pacific. In the present study, of the 29 taxa of benthic foraminifera we recovered, none are endemic, seven have Indo-Pacific affinities (Latecella reniformis, Peneroplis pertusus, Pseudohauerinella orientalis, Quinqueloculina philippiensis, Quinqueloculina subcuneata, Siphonaperta distorqueata, and Siphonina tubulosa (Brenner, 1962; Crouch and Poag, 1987; Debenay, 2012), one is a disjunct Caribbean species (Quinqueloculina vulgaris; Crouch and Poag, 1987), and most of the remaining species are tropical (Halfar et al., 2000; Halfar and Ingle, 2003) and representative of the eastern Pacific Panamic Province (Crouch and Poag, 1987).

One of the dominant taxa, Sorites, is circumtropical with the widest latitudinal distribution $\left(30^{\circ} \mathrm{S}\right.$ to $40^{\circ} \mathrm{N}$ ) of any of the larger symbiont-bearing foraminifera and whose distribution as represented by species such as Sorites orbiculus Forskål is limited by the $14^{\circ} \mathrm{C}$ winter isotherm (Langer and Hottinger, 2000; Langer, 2008). The genus is widespread in the Indo-Pacific (e.g., Cushman, 1933; Cushman et al., 1954; Cole, 1969; Langer and Lipps, 2003; Debenay, 2012; Fajemila et al., 2015), but has not reported from the eastern tropical Pacific at Rocas Alijos (McGann, 1996), the Gulf of California, Mexico (Halfar et al., 2000; Halfar and Ingle, 2003), or previously at Clipperton Island (Crouch and Poag, 1987). Instead, the dominant Soritidae reported present at the latter two locations is Amphisorus hemprichii Ehrenberg, a species which is morphologically similar to Sorites. 
The two species of planktic foraminifera recovered in the Clipperton Island deposits [Globigerinoides ruber (d'Orbigny) and Trilobatus trilobus (Reuss)] are both warm-water species that live in the upper $\sim 50$ $\mathrm{m}$ of tropical and subtropical waters (Bé and Tolderlund, 1971). Through laboratory studies, it has been shown that $G$. ruber is associated with a temperature range of $14-32^{\circ} \mathrm{C}$ and salinity of $22-49$ psu (Bé et al., 1977; Bijma et al., 1990). Clearly, these two species do not live in the intertidal to shallow subtidal waters of the island where they were retrieved but reside in the offshore water masses, their tests being carried to the nearshore after death.

\section{Dispersal of Organisms}

The transoceanic dispersal of exotic organisms into new biogeographic regions are known to occur by several processes. By far, the most likely mechanism by which organisms are dispersed into distant regions is broadcast spawners that release larvae that are capable of migrating over long distances (Richmond, 1987; Tay et al., 2012). Because the larvae have limited mobility, they depend on currents to disperse them to suitable habitats (Tay et al., 2012). Examples of such biota on Clipperton Island include mollusks (Allison and Holmes, 1971; Kaiser, 2007) and coral (Romero-Torres et al., 2018). Species with long dispersal stages are, in fact, more numerous than those species without on Clipperton Island (Kaiser, 2007). The faunal reliance on this type of dispersal ability, as well as the islands limited hard substrate biomes and paucity of other habitats (Kaiser, 2007), results in lower diversity on the island compared to most tropical Pacific regions (Allison and Holden, 1971).

Other biological introductions may be the result of rafting, such as coral larvae that have settled and grown on floating objects. These include mats of shallow-water vegetation, coconuts, logs, volcanic pumice, fishing floats, and ships' hulls (Crossland, 1952; Richards, 1958; Jokiel, 1984 and references therein). This dispersal mechanism may be fairly common. For example, the formation of vegetation mats and the release of coconuts happens daily (Lipps, personal communication, 2019). Depending on the location of currents, they could play an important role because they allow for much longer dispersal time and distance (up to several years and possibly $20,000-40,000 \mathrm{~km}$ traveled) as well as escape from predators than is possible from broadcast spawning that is only viable for short and intermediate distance dispersal (Jokiel, 1984; Richmond, 1987). Similarly, benthic foraminifera were found rafted on fishing floats, small boats, and docks from Japan to the west coast of North America and the Hawaiian Islands as a result of the Tohoku earthquake and tsunami of 2011 (Finger, 2018).

Microorganisms also may be passively distributed by being attached to, or inside of, other organisms. Two such examples are birds and fish. Allochthonous foraminifera have been reported on the feet of ducks in the Salton Sea area (Headlee, 1961) and within the guts of birds (Lipps, personal communication, 2019). Benthic foraminifera have also been recovered in the guts of shore fish that were eating food on the sediment surface (i.e., coral, algae, and possibly organic matter; Todd, 1961), as well as in the guts of invasive rabbitfish from the Red Sea that were found in the Mediterranean Sea (Guy-Haim et al., 2017). The latter is an example of ichthyochory (i.e., the live passage of organisms through fish digestive tracts) which may explain how some biological distribution patterns may be independent of oceanic currents.

Another mechanism of dispersal that has impacted Clipperton Island is due to unintentional anthropogenic efforts. In 1999-2000, a shipwreck of two large fishing boats resulted in the arrival of black rats [Rattus rattus (Linnaeus)] to the island (Pittman et al., 2006). By 2003, the rats became a common part of the island fauna. As a result, the crab and bird populations significantly declined while the vegetation increased (Pittman et al., 2006). These shipwrecks are likely responsible for the hand or foot bone (metapodial) of a mouse-size mammal found in lagoon sample LP-11.

Clipperton Island is thought to be a critical "stepping stone" in the migration pathway in the tropical Pacific (Allison and Holden, 1971; Glynn et al., 1996; Robertson and Allen, 1996; Romero-Torres et al., 2018) because it is situated on the eastern edge of the Eastern Pacific Barrier (EPB), far from any other land mass (Figure 2). Originally thought to be nearly impassable due to its expanse, as well as the relative speed of the zonal currents and the duration of larvae viability (Ekman, 1953; Thorson 1961; Heck and McCoy 
1978), biological evidence now indicates that larvae breach the EPB in both directions (Romero-Torres et al., 2018). This was confirmed by the trajectories of drifting buoys in the North Equatorial Current (NEC) and North Equatorial Countercurrent (NECC), showing their paths crossing the EPB in both directions, with one example in the NEC of them circling around Clipperton Island (Glynn et al., 1996). For most of the year, the island is situated in the path of the NEC (Figure 2A; Geography Notes, 2018). This current is the major route for organisms migrating from the American coast to Clipperton Island. As a result, 38\% of the molluscan fauna is from the eastern Pacific (Kaiser, 2007). Sea turtles have coastal affinities as well (Lorvelec et al., 2009), and two species of reef fish (Lessios and Robertson, 2006), a cone snail (Duda \& Lessios, 2009), and coral (Wood, 2013; Hellberg et al., 2016) all have been documented migrating to, and westward of, Clipperton Island from the eastern Pacific.

Occasionally, shifting currents cause Clipperton Island to be exposed to the NECC instead of the NEC (Figure 2B; Glynn et al., 1996). The easternmost land masses of the Polynesian group that lie along the course of the NECC are the Line Islands (Briggs, 1961) and those species that are well adapted for longdistance dispersal can travel eastward from those islands across the EPB to the eastern Pacific (Briggs, 1961; Dana, 1975; Jokiel, 1984; Richmond, 1987; Glynn et al., 1996; Romero-Torres, 2018). This route is especially feasible during intense El Niño events when the NECC accelerates, reducing the transport time across the Pacific by one-half or more to $\sim 50-80$ days, which is still within the length of time some larvae are capable of settlement (Richmond, 1990; Grigg and Hey, 1992; Glynn et al., 1996; Romero-Torres, 2018). The existence of this NECC faunal dispersal route is supported by evidence of tropical central Pacific and Indo-Pacific species of reef fish (Lessios and Robertson, 2006; Lessios and Balm, 2017), shore fish (Briggs, 1961), mollusks (Allison and Holden, 1971; Kaiser, 2007; Lessios and Balm, 2017), echinoderms (Lessios and Balm, 2017), and corals (Richmond, 1987; Glynn et al., 1996; Lessios and Balm, 2017).

\section{CONCLUSIONS}

Twenty-nine taxa of benthic foraminifera, two species of planktic foraminifera, 15 taxa of gastropods, and seven species of ostracods were identified from 20 beach and lagoon stations on Clipperton Island. Endemics are recognized in the molluscan and ostracod (brackish lagoon-only) faunas, but not in the foraminiferal fauna. The benthic foraminiferal fauna is primarily of tropical Indo-Pacific and eastern Pacific (Panamic) affinities with one species from the Caribbean, whereas most species of the microbiota are representative of the tropical eastern Pacific (Panamic) Province, although species with affinities to the Indo-Pacific, Inter-Island Pacific, and Caribbean Provinces are also present. Clipperton Island appears to play a role as a stepping stone for the migration of marine organisms traveling both east and west across the East Pacific Barrier by way of the surface-dwelling North Pacific Current and North Pacific Countercurrent.

\section{ACKNOWLEDGMENTS}

We would like to thank Henry W. Chaney of the Santa Barbara Museum of Natural History for allowing us access to the Allan Hancock Pacific Expedition foraminiferal microslides and Irene McCulloch's field notebook, as well as assisting in the molluscan identifications. Josh Samuels (East Tennessee State University) and Jenny McGuire (Georgia Institute of Technology) identified the mammal bone, and James Ingle, Jr. (Stanford University) provided extremely valuable comparative material from the eastern tropical Pacific for the foraminiferal portion of this investigation. Reviews of the manuscript were generously provided by Charles Powell, II (USGS), Martin Langer (University of Bonn), and Jere Lipps (University of California Museum of Paleontology). 


\section{PLATES}

Plate 1. (see p. 20) Scanning Electron Micrographs of Clipperton Island foraminiferal specimens. A. Latecella reniformis (Heron-Allen and Earland), Station LP-4. B. Planorbulina mediterranensis d'Orbigny, Station LP-1. C. Planispirillina tuberculatolimbata (Chapman), Station LP-1. D. Planispirillina tuberculatolimbata (Chapman), detail of C, Station LP-1. E. Sorites sp. 1, side view, Station LP-3. F. Sorites sp. 1, oblique view of E showing the edge with a double row of apertures, Station LP-3. G. Sorites sp. 2, edge view showing a single row of apertures, Station LP-1. H. Peneroplis pertusus (Forskål), Station LP3. I. Pseudohauerinella orientalis (Cushman), Station LP-1. J. Sigmoihauerina bradyi (Cushman), Station R-3. K. Sigmoihauerina bradyi (Cushman), Station R-3. L. Nonion pacificum (Cushman), Station LP-1. M. Loxostomina limbata (Brady), Station R-3. N. Pyrgo cf. P. oblonga (d'Orbigny), Station LP-12. O. Hauerina pacifica Cushman, Station LP-1. P. Quinqueloculina catalinensis Natland, Station R-3. Q. Quinqueloculina philippinensis Cushman, Station LP-1. R. Quinqueloculina vulgaris d'Orbigny, Station LP-1. S. Quinqueloculina subcuneata Cushman, Station LP-1. T. Siphonaperta distorqueata (Cushman), Station LP-1. U. Quinqueloculina bellatula, Station LP-10. V. Quinqueloculina sp. A, Station LP-1. W. Quinqueloculina sp. B, Station R-3. X. Quinqueloculina sp. C, Station LP-15. Y. Nodobaculariella cassis (d'Orbigny), Station LP-1. Z. Globigerinoides ruber (d'Orbigny), Station LP-1. AA. Trilobatus trilobus (Reuss), Station LP-1.

Plate 2. (see p. 21) Scanning Electron Micrographs of Clipperton Island microbiological specimens. Mollusks (A-L). A. Pachystremiscus solitarius Hertlein and Allison, Station L-3. B. Omalogyra sp., eroded specimen in ventral aspect, Station LP-1. C. Fartulum sp., Station LP-1. D. Lienardia rigida (Hinds), Station LP-3. E. ?Cerithiopsis sp., juvenile, Station LP-3. F. Turbonilla clippertonensis Hertlein and Allison, Station LP-3. G. Chrysallida limbaughi (Hertlein and Allison), Station LP-3. H. Elachisina sp., Station LP11. I. Hipponicidae sp., immature specimen, Station LP-3. J. Chrysallida limbaughi (Hertlein and Allison), protoconch, Station LP-1. K. Turbonilla clippertonensis Hertlein and Allison, protoconch, Station LP-3. L. Turbonilla clippertonensis Hertlein and Allison, protoconch, Station LP-3. Ostracods (M-Q). M. Bairdia teeteri Allison and Holden, Station LP-15. N. Cypridopsis oceanus Allison and Holden, Station LP-15. O. Limnocythere viaticum Holden and Allison, Station LP-15. P. Mutilus convergens clippertonensis Allison and Holden, Station LP-1. Q. Triebelina sertata Triebel, Station LP-1. R. Mammal bone, possibly a proximal metapodial such as a second metatarsal of a mouse-size animal, Station LP-11. Seeds (S-V). S. Seed, Station LP-11. T. Seed, Station LP-11. U. Seed, Station LP-11. V. Seed, Station LP-11. Algal reproductive structures (W-X), W. Charophyte gyrogonite, Station LP-11. X. Charophyte gyrogonite, Station LP-11.

Plate 3. (see p. 22) Scanning Electron Micrographs of Clipperton Island microbiological specimens. A, B. Fish vertebrae, Station LP-11. C. Fish bone, Station LP-11. D. Fish tooth, Station LP-11. E. Fish tooth, Station LP-1. F. Fish tooth, Station LP-1. G. Crab claw, Station LP-3. H. Crab claw, Station R-3. I. Fish tooth, Station LP-7. J. Bryozoan, Station R-3. K. Bryozoan, Station LP-1. L. Echinoid spine, Station LP-8. M. Echinoid spine, Station LP-1. N. Worm tube, Station LP-11. O. Worm tube, Station LP-15. P. Worm tube of Spirobis sp., Station LP-1. 

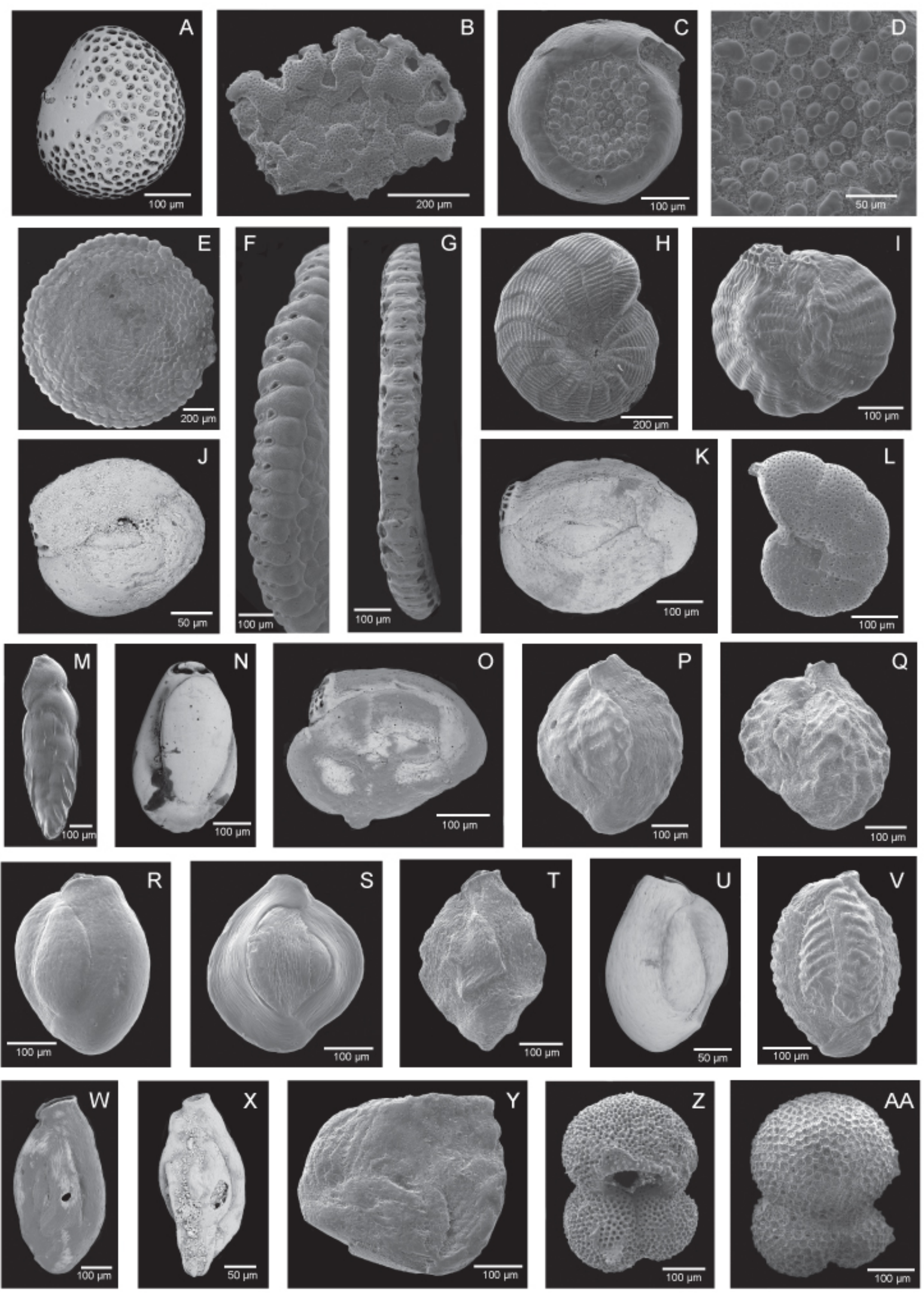

Plate 1 

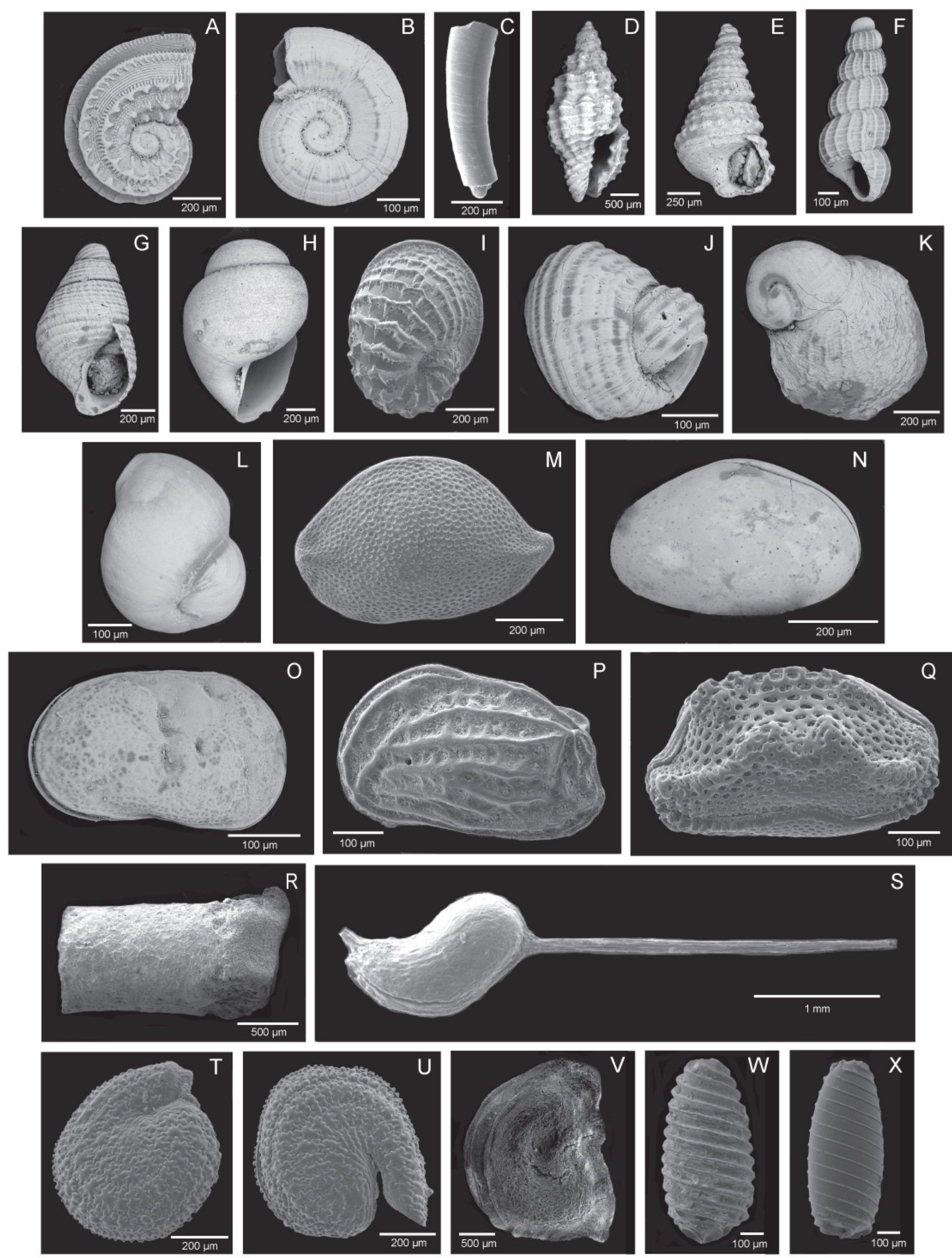

Plate 2 

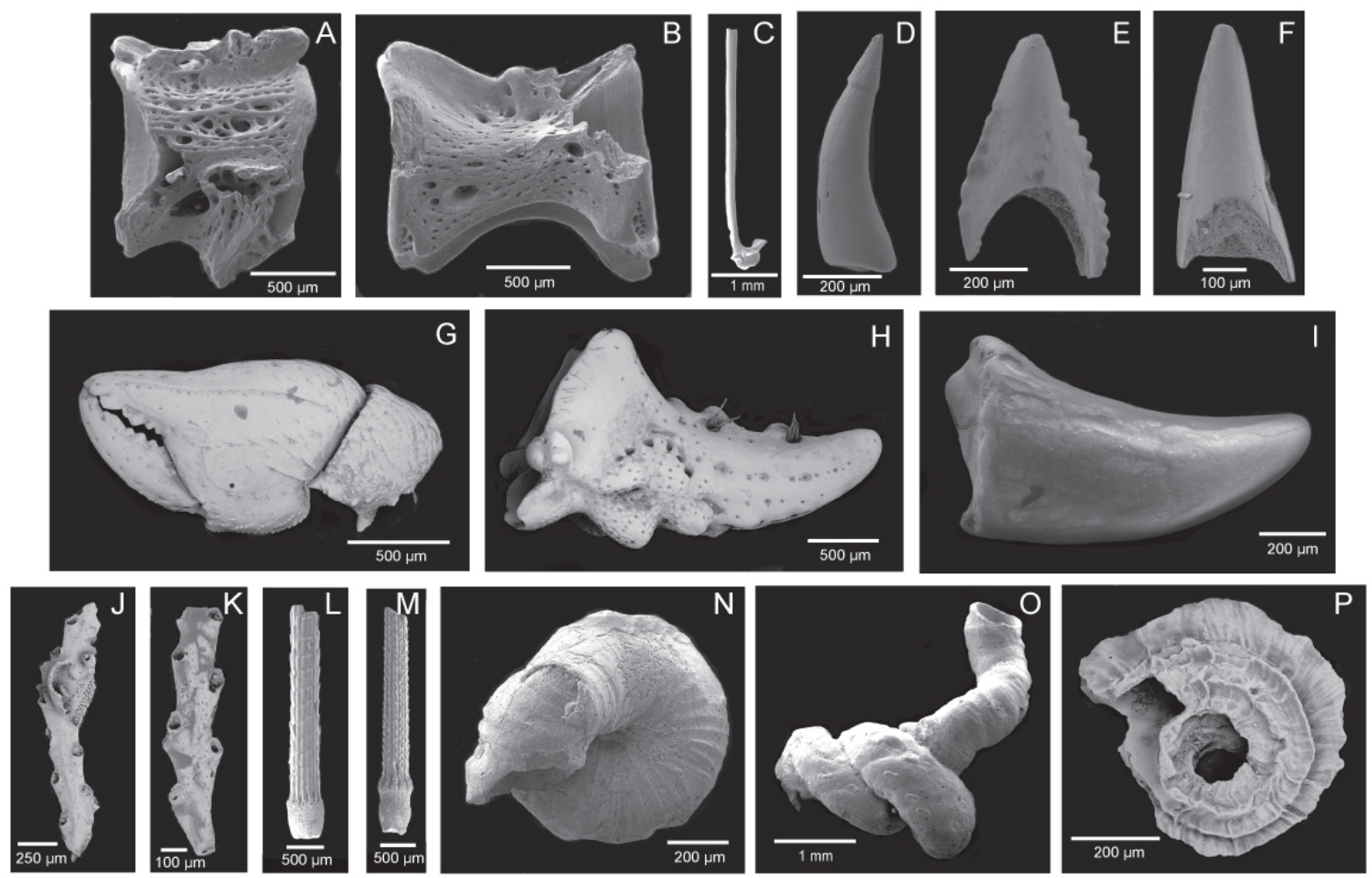

Plate 3 


\section{REFERENCES}

Allen, G. R. 1995. Clipperton: The Forgotten Island. Tropical Fish Hobbyist 475(1):46-71.

Allison, E. C., and J. C. Holden. 1971. Ostracodes from Clipperton Island eastern tropical Pacific. Transactions of the San Diego Society of Natural History 16(7):165-214.

Bartsch, P., and H. A. Rehder. 1939. Mollusks Collected on the Presidential Cruise of 1938. Smithsonian Miscellaneous Collections 98(10), Publication 3535:1-18.

Bé, A. W. H., C. Hemleben, O. R. Anderson, M. Spindler, J. Hacunda, and S. TuntivateChoy. 1977. Laboratory and Field Observations of Living Planktonic Foraminafera, Micropaleontology 23:55-179. https://doi.org/10.2307/1485330

Bé, A. W. H., and D. S. Tolderlund. 1971. Distribution and Ecology of Living Planktonic Foraminifera in Surface Waters of the Atlantic and Indian Oceans. In Micropaleontology of Oceans, ed. B. M. Funnell and W. R. Riedel, pp. 105-149. Cambridge, UK: Cambridge University Press.

Beals, M. 1995. Cowries of Clipperton. World Shells 14:73-76.

Belcher, E. 1843. Narrative of a Voyage Round the World, Performed in Her Majesty's Ship "Sulphur" during the Years 1836-1842. Vol. 1, 387 pp.; Vol. 2, 474 pp. London: Henry Colburn, https://doi.org/10.5962/bhl.title.3558

Benthic Invertebrate Collection at Scripps. 2019. Accessed at https://sioapps.ucsd.edu/collections/bi/

Bernhard, J. M. 1988. Postmortem Vital Staining in Benthic Foraminifera: Duration and Importance in Population and Distributional Studies. Journal of Foraminiferal Research 18:143-146.

Bernhard, J. M. 2000. Distinguishing Live from Dead Foraminifera; Methods Review and Proper Applications. Micropaleontology 46(1):38-46.

Bicchi, E., J.-P. Debenay, and J. Page. 2002. Relationship between Benthic Foraminiferal Assemblages and Environmental Factors in Atoll Lagoons of the Central Tuamotu Archipelago (French Polynesia). Coral Reefs 21: 275-290.

Bijma, J., W. W. J. Faber, and C. Hemleben. 1990. Temperature and Salinity Limits for Growth and Survival of Some Planktonic Foraminifers in Laboratory Cultures. Journal of Foraminiferal Research 20:95-116. https://doi.org/10.2113/gsjfr.20.2.95

Boltovskoy, E. 1976. Distribution of Recent Foraminifera of the South American Region. In Foraminifera, vol. 2, ed. R. H. Hedley and C. G. Adams, pp. 172-235. London: Academic Press.

Brenner, G. L. 1962. Results of the Puritan-American Museum of Natural History Expedition to Western Mexico, 14: A Zoogeographic Analysis of Some Shallow-Water Foraminifera in the Gulf of California. Bulletin of the American Museum of Natural History 125(5):253-297.

Briggs, J. C. 1961. The East Pacific Barrier and the Distribution of Marine Shore Fishes. Evolution 15:545554.

Carricart-Ganivet, J. P., and H. Reyes-Bonilla. 1999. New and Previous Records of Scleractinian Corals from Clipperton Atoll, Eastern Pacific. Pacific Science 53(4):370-375.

Charpy, L., M. Rodier, A. Couté, C. Perrette-Gallet, and C. Bley-Loëz. 2010. Clipperton, a Possible Future for Atoll Lagoons. Coral Reefs 29:771-783.

Cole, S. 1969. Larger Foraminifera from Deep Drill Holes on Midway Atoll. U.S. Geological Survey Professional Paper 680-C:C1-C15.

Combosch, D. J, H. M. Guzman, H. Schuhmacher, and S. V. Vollmer. 2008. Interspecific Hybridization and Restricted Trans-Pacific Gene Flow in the Tropical Eastern Pacific Pocillopora. Molecular Ecology 17(5):1304-1312.

Cousteau, J. 1981. The Cousteau's Odyssey-Clipperton: The Island Time Forgot. Television series filmed in 1980, episode 8 of 12. https://www.youtube.com/watch?v=pfmgajTWruU

Crossland, C. 1952. Madreporaria, Hydrocorallinae, Heliopora and Tubipora. Scientific Reports of the Great Barrier Reef Expedition 6:86-257.

Crouch, R. W., and C. W. Poag. 1987. Benthic Foraminifera of the Panamanian Province: Distribution and Origins. Journal of Foraminiferal Research 17(2):153-176. 
Culver, S. J., and M. A. Buzas. 1986. Distribution of Recent Benthic Foraminifera Off the North American Pacific Coast from California to Baja. Smithsonian Contributions to the Marine Sciences, no. 28, 634 pp. https://doi.org/10.5479/si.01960768.28.1

Culver, S. J., and M. A. Buzas. 1987. Distribution of Recent Benthic Foraminifera Off the Pacific Coast of Mexico and Central America. Smithsonian Contributions to the Marine Sciences, no. 30, 184 pp. https://doi.org/10.5479/si.01960768.30.1

Cushman, J. A. 1933. The Foraminifera of the Tropical Pacific Collections of the Albatross, 1899-1900. Part 2. Lagenidae to Alveolinellidae. U.S. National Museum Bulletin 161:1-79.

Cushman, J. A., R. Todd, and R. Post. 1954. Recent Foraminifera of the Marshall Islands. Bikini and Nearby Atolls: Pt. 2, Oceanography (Biologic). U.S. Geological Survey Professional Paper 260-H:319-384.

Cushman, J. A., and I. McCulloch. 1939. A Report on Some Arenaceous Foraminifera. Allan Hancock Pacific Expeditions. Los Angeles, University of Southern California Press, 6(1):1-113.

Cushman, J. A., and I. McCulloch. 1942. Some Virgulininae in the Collections of the Allan Hancock Foundation. Allan Hancock Pacific Expeditions. Los Angeles, University of Southern California Press, 6(4):181-230.

Cushman, J. A., and I. McCulloch. 1948. The Species of Bulimina and Related Genera in the Collections of the Allan Hancock Foundation. Allan Hancock Pacific Expeditions. Los Angeles, University of Southern California Press, 6(5):231-294.

Debenay, J.-P. 2012. A Guide to 1,000 Foraminifera from Southwestern Pacific: New Caledonia. IRD Éditions. Paris: Institut de recherche pour le développement, French National Museum of Natural History. 378 pp.

Duda, T. F., Jr., and H. A. Lessios. 2009. Connectivity of Populations within and between Major Biogeographic Regions of the Tropical Pacific in Conus ebraeus, a Widespread Marine Gastropod. Coral Reefs 28:651-659.

Ekman, S. P. 1953. Zoogeography of the Sea (transl. from Swedish by Elizabeth Parker). London: Sedgwick and Jackson, XIV. 417 pp.

Emerson, W. K. 1967. Indo-Pacific Faunal Elements in the Tropical Eastern Pacific, with Special Reference to the Mollusks. Venus 25:85-93.

Emerson, W. K. 1994. A Zoogeographic Summary of the Marine Mollusks of Clipperton Island (Tropical Eastern Pacific Ocean). Festivus 26:62-71.

Emerson, W. K., and H. W. Chaney. 1995. A Zoogeographic Review of the Cypraeidae (Mollusca:Gastropoda) Occurring in the Eastern Pacific Ocean. Veliger 38:8-21.

Fajemila, O. T., M. R. Langer, and J. H. Lipps. 2015. Spatial Patterns in the Distribution, Diversity and Abundance of Benthic Foraminifera around Moorea (Society Archipelago, French Polynesia). PLoS One 10(12):e0145752. https://doi.org/10.1371/journal.pone.0145752

Finger, K. L. 2018. Tsunami-Generated Rafting of Foraminifera across the North Pacific Ocean. Aquatic Invasions 13(1):17-30.

Flot, J.-F., and M. Adjeroud. 2009. Les Coraux de Clipperton. In Clipperton: Environnement et Biodiversité d'Unmicrocosme Océanique, Tome 68, ed. L. Charpy. Paris: Patrimoines Naturels, Muséum National d'Histoire Naturelle.

Förderer, M., and M. R. Langer. 2018. Atlas of Benthic Foraminifera from Coral Reefs of the Raja Ampat Archipelago (Irian Jaya, Indonesia). Micropaleontology 64(1-2), 170 pp.

Förderer, M., D. Rödder, and M. R. Langer. 2018. Patterns of Species Richness and the Center of Diversity in Modern Indo-Pacific Larger Foraminifera. Scientific Reports (2018) 8:8189.

Fujita, K., and A. Omori. 2015. Modern and Pleistocene Large-Sized Benthic Foraminifers from Tahiti, French Polynesia, Collected during IODP Expedition 310. Island Arc 24:47-60, https://doi.org/10.1111/iar.12069

Geography Notes. 10 Main Currents in the Pacific Ocean. http://www.geographynotes.com/oceans/pacificocean/10-main-currents-in-the-pacific-ocean-oceans-geography/2666 (accessed May 2019). 
Glynn, P. W., J. E. N. Veron, and G. M. Wellington. 1996. Clipperton Atoll (Eastern Pacific): Oceanography, Geomorphology, Reef-Building Coral Ecology and Biogeography. Coral Reefs 15:7199.

Goldberg, W. M. 2016. Atolls of the Word: Revisiting the Original Checklist. Atoll Research Bulletin 610:1-47.

Gorshkov, S. G., ed. 1976. World Ocean Atlas Volume 1 Pacific Ocean (English version). Oxford, UK: Pergamon Press.

Grigg, R. W., and R. Hey. 1992. Paleoceanography of the Tropical Eastern Pacific Ocean. Science 255:172178.

Guy-Haim, T., O. Hyams-Kaphzan, E. Yeruham, A. Almogi-Labin, and J. T. Carlton. 2017. A Novel Marine Bioinvasion Vector: Ichthyochory, Live Passage through Fish. Limnology and Oceanography Letters 2:80-89.

Halfar, J., L. Godinez-Orta, and J. C. Ingle, Jr. 2000. Microfacies Analysis of Recent Carbonate Environments in the Southern Gulf of California, Mexico: A Model for Warm-Temperate to Subtropical Carbonate Formation. Palaios 15(4):323-342.

Halfar, J., and J. C. Ingle, Jr. 2003. Modern Warm-Temperate and Subtropical Shallow-Water Benthic Foraminifera of the Southern Gulf of California, Mexico. Journal of Foraminiferal Research 33(4):309-329.

Hallock, P. 1981. Production of Carbonate Sediments by Selected Foraminifera on Two Pacific Coral Reefs. Journal of Sedimentary Research 51:467-474.

Headlee, L., 1961. Transportation of Foraminifera by Ducks. University of Southern California, unpublished term paper.

Heck, K. L., Jr., and E. D. McCoy. 1978. Long-Distance Dispersal and the Reef-Building Corals of the Eastern Pacific. Marine Biology 48:349-356.

Hellberg, M. E., C. Prada, M. H. Tan, Z. H. Forsman, and I. B. Baums. 2016. Getting a Grip at the Edge: Recolonization and Introgression in Eastern Pacific Porites Corals. Journal of Biogeography 43(11):2147-2159. https://doi.org/10.1111/jbi.12792

Hertlein, L. G., and W. K. Emerson. 1953. Mollusks from Clipperton Island (Eastern Pacific) with the Description of a New Species of Gastropod. Transactions of the San Diego Society of Natural History II (13):345-364.

Holzmann, M., J. Hohenegger, P. Hallock, W. E. Piller, and J. Pawlowski. 2001. Molecular Phylogeny of Large Miliolid Foraminifera (Soritacea Ehrenberg, 1839). Marine Micropaleontology 43(1):57-74.

Humphreys, A. F., J. Halfar, J. C. Ingle, D. Manzello, C. E. Reymond, H. Westphal, and B. Riegl. 2019. Shallow-Water Benthic Foraminifera of the Galápagos Archipelago: Ecologically Sensitive Carbonate Producers in an Atypical Tropical Oceanographic Setting. Journal of Foraminiferal Research 49:4865.

Jokiel, P. L. 1984. Long Distance Dispersal of Reef Corals by Rafting. Coral Reefs 3:113-116.

Jost, C. H., and S. Andrefouët. 2006, Long Term Natural and Human Perturbations and Current Status of Clipperton Atoll, a Remote Island of the Eastern Pacific. Pacific Conservation Biology 12(3):207-218.

Kaiser, K. L. 2007. The Recent Molluscan Fauna of Île Clipperton (Tropical Eastern Pacific). The Festivus Vol. XXXIX Supplement, $161 \mathrm{pp}$.

Koblentz-Mishke O. J., V. V. Volkovinsky, and J. G. Kabanova. 1970. Plankton Primary Production of the World Ocean. In Scientific Exploration of the South Pacific, ed. W. S. Wooster, pp. 183-193. Washington, D.C.: National Academy of Sciences.

Langer, M. R. 2008. Foraminifera from the Mediterranean and the Red Sea. In Aqaba-Eilat, the Improbable Gulf. Environment, Biodiversity and Preservation, ed. F. D. Por, pp. 397-415. Jerusalem: Hebrew University Magnes Press.

Langer, M. R., and L. Hottinger. 2000. Biogeography of Selected Larger Foraminifera. In Biology of Foraminifera, v. 46, suppl. 1, ed. J. J. Lee, pp. 105-126. New York: Micropaleontology Press. 
Langer, M. R., and J. H. Lipps. 2003. Foraminiferal Distribution and Diversity, Madang Reef and Lagoon, Papua New Guinea. Coral Reefs 22:143-154.

Langer, M. R., and J. H. Lipps. 2006. Assembly and Persistence of Foraminifera in Introduced Mangroves on Moorea, French Polynesia. Micropaleontology 52(4):343-355.

Lessios, H.A., and I. B. Baums. 2017. Gene Flow in Coral Reef Organisms of the Tropical Eastern Pacific. In Coral Reefs of the Eastern Tropical Pacific: Persistence and Loss in a Dynamic Environment, ed. P. W. Glynn, D. Manzello, and I. C. Enochs, pp. 477-499. Netherlands: Springer.

Lessios, H. A., and D. R. Robertson. 2006. Crossing the Impassable: Genetic Connections in 20 Reef Fishes across the Eastern Pacific Barrier. Proceedings of the Royal Society B: Biological Sciences 273:22012208.

Lévesque, R. 1998. French Ships at Guam, 1708-1717: Introduction to a Little-Known Period in Pacific History. The Journal of Pacific History 33(1):105-110.

Limbaugh, C. 1959. August-September 1958. Field Report. IGY Clipperton Island Expedition. SIO Reference 59-13:1-7. San Diego: University of California San Diego, Scripps Institution of Oceanography. https://escholarship.org/uc/item/20c152nj

Lindberg, D. R., B. Roth, M. G. Kellogg, and C. L. Hubbs. 1980. Invertebrate Megafossils of Pleistocene (Sangamon Interglacial) Age from Isla de Guadalupe, Baja California, Mexico. In The California Islands: Proceedings of a Multidisciplinary Symposium, ed. D. M. Powers, pp. 41-62. Santa Barbara, Calif.: Santa Barbara Museum of Natural History.

Lorvelec, O., M. Pascal, and J. Fretey. 2009. Sea Turtles on Clipperton Island (Eastern Tropical Pacific). Marine Turtle Newsletter 124:10-13.

Lutze, G.-F., and A. Altenbach, 1991. Technik und signifikanz der Lebendfarbun benthischer Foraminiferen mit Bengalrot. Geologisches Jahrbuch A 128:251-265.

Makled, W. A., and M. R. Langer. 2011. Benthic Foraminifera from the Chuuk Lagoon Atoll System (Caroline Islands, Pacific Ocean). Neues Jahrbuch für Geologie und Paläontologie 259(2):231-249.

McCulloch, I. 1977. Qualitative Observations on Recent Foraminiferal Tests with Emphasis on the Eastern Pacific. Los Angeles: University of Southern California. 1078 pp.

McGann, M. 1996. Foraminifera of Rocas Alijos. In Rocas Alijos: Results of the 1990 and 1993 Scientific Expeditions, ed. R. W. Schmieder, pp. 177-220. Dordrecht, Netherlands: Kluwer Academic Publishers.

McKee, E. D., J. Chronic, and E. B. Leopold. 1959. Sedimentary Belts in the Lagoon of Kapingimarangi Atoll. Bulletin of the American Association of Petroleum Geologists 43:501-562.

Menard, H. W., and R. L. Fisher. 1958. Clipperton Fracture Zone in the Northeastern Equatorial Pacific. Journal of Geology 66:239-253.

Merkado, G., M. Holzmann, L. Apothéloz-Perret-Gentil, J. Pawlowski, U. Abdu, A. Almogi-Labin, O Hyams-Kaphzan, A. Bakhrat, and S. Abramovich. 2013. Molecular Evidence for Lessepsian Invasion of Soritids (Larger Symbiont Bearing Benthic Foraminifera). PLOS One 8(10): e77725. https://doi.org/10.1371/journal.pone.0077725

Moberly, R., Jr., and T. Chamberlain. 1964. Hawaiian Beach Systems. Hawaii Institute of Geophysics Report 64-2. Honolulu: University of Hawaii.

Muller, P. H. 1981. Production of Carbonate Sediments by Selected Large Benthic Foraminifera on Two Pacific Coral Reefs. Journal of Sedimentary Petrology 51:467-474.

Parsons, T. R., and M. Takahashi. 1973. Biological Oceanographic Processes. New York: Pergamon Press. $186 \mathrm{pp}$.

Perrin, B. 1977. Two Days on Clipperton - or Getting High on Boobies. The Festivus 8(4):24-26.

Pittman, R. L., L. T. Balance, and C. Bost. 2006. Clipperton Island: Pig Sty, Rat Hole, and Booby Prize. Marine Ornithology 33:193-194.

Poupin, J., J.-M. Bouchard, L. Albenga, R. Cleva, M. Hermoso-Salazar, and V. Solís-Weiss. 2008. Les Crustacés de l'atoll de Clipperton, inventaire, écologie, et zoogéographie (Decapoda, Stomatopoda). In Clipperton: Environnement et Biodiversité d'Unmicrocosme Océanique, Tome 68, ed. L. Charpy. Paris: Patrimoines Naturels, Muséum National d'Histoire Naturelle. 
Richards, A. F. 1958. Transpacific Distribution of Floating Pumice from Isla San Benedicto, Mexico. DeepSea Research 5:29-35.

Richmond, R. H. 1987. Energetics, Competency, and Long-Distance Dispersal of Planula Larvae of the Coral Pocillopora damicornis. Marine Biology 93:527-533.

Richmond, R. H. 1990. The Effects of the E1 Niño/Southern Oscillation on the Dispersal of Corals and Other Marine Organisms. In Global Ecological Consequences of the 1982-83 E1 Niño-Southern Oscillation, ed. P. W. Glynn. Elsevier Oceanography Series 52(1990):127-140.

Robertson, D. R., and G. R. Allen. 1996. Zoogeography of the Shorefish Fauna of Clipperton Atoll. Coral Reefs 15:121-131.

Sachet, M.-H. 1960. Histoire de l'île Clipperton. Cahiers du Pacifique 2:3-32.

Sachet, M.-H. 1962a. Flora and Vegetation of Clipperton Island. Proceedings of the California Academy Sciences, Series 4, 31(10):249-307.

Sachet, M.-H. 1962b. Geography and Land Ecology of Clipperton Island. Atoll Research Bulletin 86:1115.

Sachet, M.-H. 1962c. Monographie physique et biologique d l'ile Clipperton. Annales de l'Institut Océanographique (Paris) 40:1-107.

Sachet, M.-H. 1963. History of Change in the Biota of Clipperton Island. In Pacific Basin Biogeography Symposium, ed. J. L. Gressit, pp. 525-534. Honolulu: Bishop Museum Press.

Schmieder, R. W. (KK6EK). 2013. =DXA= The Real-Time Online Radio Log Server. Walnut Creek, Calif.: Cordell Expeditions. 248 pp.

Schneider, B. 2004. A Fisherman Explores Clipperton Island. The Festivus 36(4):37-40.

Skaggs, J. M. 1989. Clipperton: A History of the Island the World Forgot. New York: Walker Publishing Company. 318 pp.

Skinner, R. K, and R. W. Schmieder. 1996. Discovery and Exploration of Rocas Alijos. In Rocas Alijos: Scientific Results from the Cordell Expeditions, ed. R. W. Schmieder, pp. 11-42. Dordrecht, Netherlands: Kluwer Academic Publishers.

Small, M. 1994. Clipperton '94: An Initial Report. The Festivus 26(7):78-83.

Small, M. 1995. Clipperton: Where the Panamic and Indo-Pacific Meet. World Shells 13:108-112.

Solis-Marin, F. A., and A. Laguarda Figueras. 2009. Les Echinodermes de Clipperton. In Clipperton: Environnement et Biodiversité d'Unmicrocosme Océanique, Tome 68, ed. L. Charpy. Paris: Patrimoines Naturels, Muséum National d'Histoire Naturelle.

Sournia, A. 1976. Primary Production of Sands in the Lagoon of an Atoll and the Role of Foraminiferal Symbionts. Marine Biology 37:29-32.

Tay, Y. C., P. A. Todd, P. S. Rosshaug, and L. M. Chou. 2012. Simulating the Transport of Broadcast Coral Larvae among the Southern Islands of Singapore. Aquatic Biology 15:283-297.

Teall, J. J. H. 1898. A Phosphatized Trachyte from Clipperton Atoll (Northern Pacific). Quaternary Journal of the Geological Society (London) 54(2):230-232.

Thorson, G. 1961. Length of Pelagic Larval Life in Marine Bottom Invertebrates as Related to Larval Transport by Ocean Currents. In Oceanography, ed. M. Sears. American Association for the Advancement of Science 67:455-474.

Todd, R. 1961. Foraminifera from Onotoa Atoll, Gilbert Island. U.S. Geological Survey Professional Paper 354-H:171-191.

Vénec-Peyré, M. T. 1991. Distribution of Living Benthic Foraminifera on the Back-Reef and Outer Slopes of a High Island (Moorea, French Polynesia). Coral Reefs 9:193-203.

Weinmann A. E., D. Rödder, S. Lötters, and M. R. Langer. 2013. Heading for New Shores: Projecting Marine Distribution Ranges of Selected Larger Foraminifera. PLoS ONE 8(4):e62182. https://doi.org/10.1371/journal.pone.0062182

Whittaker, J. E., and R. L. Hodgkinson. 1995. The Foraminifera of the Pitcairn Islands. Biological Journal of the Linnean Society 56:365-371. 
Wood, S., C. B. Paris, A. Ridgwell, and E. J. Hendy. 2013. Modelling Dispersal and Connectivity of Broadcast Spawning Corals at the Global Scale. Global Ecology and Biogeography 23:1-11. https://doi.org/10.1111/geb.12101 